\title{
Feeding and oviposition behaviour of a gall inducing species of Glycaspis (Synglycaspis) (Hemiptera: Psylloidea: Aphalaridae) and development of galls on the leaves of Eucalyptus macrorhyncha (Myrtaceae) in central western New South Wales, Australia
}

\author{
Anamika SHARMA ${ }^{1}$, Anantanarayanan RAMAN ${ }^{1,2, *}$, Gary S. TAYLOR ${ }^{3}$, Murray J. FLETCHER ${ }^{1,2,4}$ \\ and HELEN I. NICOL ${ }^{1}$ \\ ${ }^{1}$ Charles Sturt University, PO Box 883, Orange, NSW 2800, Australia; e-mails: araman@csu.edu.au; asharma@csu.edu.au; \\ murvic@aanet.com.au; helen.i.nicol@gmail.com \\ ${ }^{2}$ Graham Centre for Agricultural Innovation, Locked Bag 588, Wagga, NSW 2678, Australia \\ ${ }^{3}$ Australian Centre for Evolutionary Biology \& Biodiversity and the School of Earth and Environmental Sciences, \\ University of Adelaide, Adelaide, SA 5005, Australia; e-mail: gary.taylor@adelaide.edu.au \\ ${ }^{4}$ Orange Agricultural Institute, Forest Road, Orange, NSW 2800, Australia
}

Key words. Hemiptera, Psylloidea, Aphalaridae, Glycaspis (Synglycaspis), Eucalyptus, galls, cecidogenesis, host-specificity, nutritive cells, oviposition

\begin{abstract}
Glycaspis (Synglycaspis) confined to Australia includes gall-inducing and lerp-forming species that are probably highly specific to different species of Eucalyptus subgenus Eucalyptus. Based on available information, their distribution appears restricted to temperate, south-eastern and southern Australia. This paper reports the biology of an unnamed (suspected new species) of Glycaspis (Synglycaspis) that induces spherical, ostiolate galls on the leaves of Eucalyptus macrorhyncha in central western tablelands of NSW. This species completes two generations in a year. Oviposition elicits a passive response in the leaves of E. macrorhyncha. In this work we demonstrate that the host tissue not only supplies water, but also nutrients to the developing embryo via the embedded pedicel. Feeding action of the first instar initiates the gall and morphogenetic gradients become apparent around the feeding site. These gradients direct gall growth. The gall attains its near final spherical shape during the second instar and this spherical gall remains plugged with sugary material, which all the immature stages secrete from the last abdominal segment. No significant gall growth occurs during the occupation of the gall by the third, fourth and fifth instars. The first and second instars feed on the newly differentiated parenchyma tissue in galls, whereas the third, fourth and fifth instars feed on phloem of galls. Consequently the multi-layer parenchymatous nutritive tissue that initially develops lining the chamber dries and shrivels, when the later instars inhabit galls. This shrinkage induces a gradual thinning of gall walls, which is also aggravated by modest expansive growth of the gall.
\end{abstract}

\section{INTRODUCTION}

The Psylloidea, comprising almost 4000 species globally, occur in nearly all major climatic regions of the world (Hodkinson, 2009). About 380 described species of Psylloidea occur in Australia with impressive radiations in species of Spondyliaspidinae (Aphalaridae) on Eucalyptus L'Hér., Acizzia Heslop-Harrison (Psyllidae) on different species of Fabaceae and, to a lesser extent, Triozidae on a few species of Casuarinaceae (Yen, 2002; Hollis, 2004; Taylor, 2010, 2011). Collectively about $40 \%$ of the described Australian Psylloidea are free living, 50\% are lerp forming and 10\% are gall inducing (Hollis, 2004; Sharma et al., 2013; Taylor et al., 2013). The Psylloidea generally exhibit a high level of host specificity with many species developing either on single or on closely related host species and a few of them are of importance in horticulture and forestry (Hollis, 2004).

Among Psylloidea, the gall inducing species occur in the Triozidae, Aphalaridae, Calophyidae, Homotomidae, Pha- copteronidae, Liviidae and Psyllidae (Burckhardt, 2005; Yang \& Raman, 2007). Different gall-inducing species of the Psylloidea induce different types of galls: leaf-roll galls, e.g., Lauritrioza alacris (Flor) [= Trioza alacris] (Triozidae) on Laurus nobilis L. (Lauraceae) (Bouyjou \& Nguyen, 1974), pit galls, e.g., Trioza ocoteae Houard on Ocotea acutifolia (Nees) Mez. (Lauraceae) (Meyer, 1987), spherical, pouch galls, e.g., Pseudophacopteron tuberculatum (Crawford) (Phacopteronidae) on Alstonia scholaris (L.) R. Br. (Apocynaceae) (Albert et al., 2011) and spherical, closed galls, e.g., Trioza jambolanae Crawford on Syzygium cumini L. (Myrtaceae) (Raman, 1991).

Glycaspis, with two subgenera Glycaspis (sensu stricto) and Synglycaspis, is differentiated from the rest of Spondyliaspidinae by the wing venation and distinctly elongate genal processes (Burckhardt, 1991). The immatures of the former construct lerps, whereas those of the latter induce galls in addition to secreting sugary material that plugs the gall ostiole. The known species of Glycaspis (Synglycaspis) are from the south-eastern states of Australia (Ta-

\footnotetext{
* Corresponding author.
} 
TABLE 1. Gall-inducing Glycaspis (Synglycaspis) taxa in south-eastern Australia. (Source: Moore, 1961, 1970, 1979, 1985, 1988; Hollis, 2004.)

\begin{tabular}{|c|c|c|}
\hline Species of Glycaspis & $\begin{array}{c}\text { Species of } \\
\text { Eucalyptus (Eucalyptus) }\end{array}$ & $\begin{array}{c}\text { Distribution (Bioregions)* } \\
\text { Specific localities shown in square brackets }\end{array}$ \\
\hline $\begin{array}{l}\text { G. (S.) amplificata } \\
{[=G .(\text { G. }) \text { amplificata }]}\end{array}$ & $\begin{array}{l}\text { E. acmenoides } \\
\text { E. triantha }\end{array}$ & $\begin{array}{c}\text { Sydney Basin } \\
\text { [Ourimbah State Forest, } 500 \text { m a.s.1.] }\end{array}$ \\
\hline G. (S.) belua & E. pauciflora & $\begin{array}{l}\text { South-Eastern Highlands } \\
\text { [Mt Gingera, } 1800 \text { m a.s.l.] }\end{array}$ \\
\hline G. (S.) brunosa & E. coccifera & $\begin{array}{c}\text { Tasmanian South-East } \\
\text { [Mount Wellington, } 1200 \mathrm{~m} \text { a.s.1.] }\end{array}$ \\
\hline G. (S.) cameloides & E. obliqua & $\begin{array}{l}\text { Flinders Lofty Block } \\
\text { [Uraidla, } 500 \mathrm{~m} \text { a.s.1.] }\end{array}$ \\
\hline G. (S.) cellula & E. amygdalina & $\begin{array}{l}\text { Ben Lomand } \\
\text { [St Helen's] }\end{array}$ \\
\hline G. $(S$.$) commoni * * *$ & Not known & - \\
\hline G. (S.) constricta & E. stricta & $\begin{array}{c}\text { Sydney Basin } \\
\text { [Kings Tableland, } 1000 \text { m a.s.l.] }\end{array}$ \\
\hline $\begin{array}{l}\text { G. }(S .) \text { cyrtoma } \\
{[=\text { G. }(\text { G. }) \text { cyrtoma }]}\end{array}$ & E. piperita & $\begin{array}{c}\text { Sydney basin } \\
\text { [Olney State Forest, } 150 \text { m a.s.1.] }\end{array}$ \\
\hline $\begin{array}{l}\text { G. }(S .) \text { cyta } \\
{[=G .(G .) \text { cytos }]} \\
\end{array}$ & E. pilularis & $\begin{array}{c}\text { New South Wales North Coast } \\
\text { [Kincumber, } 200 \text { m a.s.l.] }\end{array}$ \\
\hline G. (S.) ecphymata & E. dives & $\begin{array}{l}\text { South-East Coastal Plains } \\
\text { [Dandenong, } 600 \mathrm{~m} \text { a.s.1.] }\end{array}$ \\
\hline $\begin{array}{l}\text { G. (S.) encytis } \\
{[=G .(G .) \text { encytis }]}\end{array}$ & E. agglomerata & $\begin{array}{c}\text { Sydney Basin } \\
\text { [Ourimbah State Forest, } 500 \text { m a.s.1.] }\end{array}$ \\
\hline G. (S.) immaceria & E. rossii & $\begin{array}{c}\text { South-Eastern Highlands } \\
\text { [Black Mountain, } 800 \mathrm{~m} \text { a.s.l.] }\end{array}$ \\
\hline $\begin{array}{l}\text { G. (S.) inclusa } \\
{[=G .(G .) \text { inclusa }]}\end{array}$ & $\begin{array}{l}\text { E. umbra } \\
\text { E. macrorhyncha }\end{array}$ & $\begin{array}{c}\text { South-Eastern Highlands } \\
\text { [Black Mountain, } 800 \mathrm{~m} \text { a.s.l.] } \\
\text { New South Wales North Coast } \\
\text { [Mangrove Mountain, } 300 \mathrm{~m} \text { a.s.l.] }\end{array}$ \\
\hline G. (S.) longaeva & E. pulchella & $\begin{array}{l}\text { Tasmanian South-East } \\
\text { [Hobart, } 900 \mathrm{~m} \text { a.s.l.] }\end{array}$ \\
\hline G. (S.) morgani & E. diversifolia & $\begin{array}{c}\text { Flinders Lofty Block } \\
\text { [Point Davenport, } 100 \mathrm{~m} \text { a.s.1.] }\end{array}$ \\
\hline$\overline{G .(S .) \text { munita }}$ & E. nitida & $\begin{array}{c}\text { Tasmanian West } \\
\text { [Queenstown, } 100 \mathrm{~m} \text { a.s.1.] }\end{array}$ \\
\hline G. (S.) obvelata & E. sieberi & $\begin{array}{c}\text { New South Wales*** } \\
\text { Victoria** } \\
\text { Tasmania** }\end{array}$ \\
\hline$\overline{G .(S .) \text { occulta }}$ & $\begin{array}{l}\text { E. macrorhyncha } \\
\text { E. simmondsii }\end{array}$ & $\begin{array}{c}\text { South-Eastern Highlands } \\
\text { [Black Mountain, } 800 \mathrm{~m} \text { a.s.1.] } \\
\text { Tasmanian Northern Slope } \\
\text { [Inglis river, } 500 \mathrm{~m} \text { a.s.1.] }\end{array}$ \\
\hline $\begin{array}{l}\text { G. }(S .) \text { perthecata } \\
{[=G .(G .) \text { perthecata }]}\end{array}$ & E. haemastoma & $\begin{array}{c}\text { Sydney Basin } \\
\text { [Ourimbah State Forest, } 500 \mathrm{~m} \text { a.s.1.] }\end{array}$ \\
\hline G. (S.) surculina & E. conglomerata & $\begin{array}{l}\text { South-Eastern Queensland } \\
\text { [ Beerwah, } 100 \mathrm{~m} \text { a.s.1.] }\end{array}$ \\
\hline
\end{tabular}

* Department of Environment, Government of Australia, 2012. ** Specific localities not available.

ble 1). Host relations of the known species of Glycaspsis (Synglycaspis) indicate that most of them occur on species of Eucalyptus subgenus Eucalyptus. Glycaspis (Synglycaspis) cyanoreia Moore, a lerp former, develops on different species of Eucalyptus subgenus Eucalyptus and Eucalyptus subgenus Symphyomyrtus (Moore, 1961, 1983, 1985, 1988).

Glycaspis $(S$.) cameloides Moore, which induces pouch galls on the leaves of Eucalyptus obliqua L'Hér., from the
Mount Lofty Ranges, South Australia (351'S; $\left.138^{\circ} 46^{\prime} \mathrm{E}\right)$, is the only species for which details of biology have been published (Taylor, 1987). Settling on the adaxial surfaces of $E$. obliqua leaves, the feeding action of the first instars of $G$. (S.) cameloides induces an invagination around the feeding site that grows into a thin-walled pouch gall manifesting on the abaxial leaf surfaces. The pouch ostiole is plugged by a "material" secreted by the immatures; the material extends into the interior of the gall in the form 
of either a ball or a column. By manipulating the plug, the fifth instars exit the gall through the ostiole to moult into adults outside. Two generations of $G$. (S.) cameloides occur in a year (Taylor, 1987). Nothing further is available on the biology and behaviour of this group of psylloids. The present paper, therefore, reports the development of galls together with biological and behavioural notes for a suspected new species of Glycaspis (Synglycaspis) developing on the leaves of E. macrorhyncha in Central western New South Wales. The galls induced by Glycaspis $(S$.) sp. on E. macrorhyncha are spherical with defined ostioles and are externally similar to those induced by Glycaspis $(S$.) cameloides on the leaves of Eucalyptus obliqua (Taylor, 1987).

Glycaspis is a large, morphologically conserved genus with over 140 species that are generally specific to one or several closely related hosts. Of these, 43 species belong to the subgenus Synglycaspis and of which two are recorded from widely separated localities on E. macrorhyncha (Hollis, 2004). Due to morphological similarity between species (see Moore, 1961, 1970) the identity of focal species could not be determined with certainty, indeed whether or not it represented an additional new undescribed species. Conservatively we place it as Glycaspis (Synglycaspis) sp. from $E$. macrorhyncha and will refer to it hereafter as $G$. (S.) sp. on E. macrorhyncha. Terminology for life stages used in this paper follows Burckhardt et al. (2014).

\section{MATERIAL AND METHODS}

\section{Study site, sampling periods}

Populations of eggs, immatures and adults of Glycaspis (Synglycaspis) sp. were obtained from E. macrorhyncha, growing in the Eldorado Nature Reserve Area (ENRA), a component of the Mullion Range State Conservation Area in October 2012-March 2013 and Mullion Creek Range (MCR) in October 2013-March 2014. Both ENRA and MCR are situated in the Orange region of the South Eastern Highlands Bioregion of New South Wales. The Orange region $\left(33^{\circ} 17^{\prime} \mathrm{S}, 149^{\circ} 6^{\prime} \mathrm{E}\right)$ occurs at $\sim 900 \mathrm{~m}$ a.s.l. and receives an annual mean rainfall of $120 \mathrm{~cm}$, experiencing an annual mean summer (December-February) temperature of $18^{\circ} \mathrm{C}$ and winter (June-August) temperature of $5^{\circ} \mathrm{C}$. ENRA and MCR are separated by a distance of $50 \mathrm{~km}$. MCR experienced a fire event in 2009-2010, which enabled the germination of new seedlings in 2013-2014, in turn enabling the establishment of populations of $G$. (S.) sp. on E. macrorhyncha at MCR. The population data from 2013-2014 were processed in GenStat ${ }^{\mathrm{TM}}$ (VSN International, 2013) for linear regression. A polynomial was fitted to all the data ignoring the stages viz., eggs, immatures and adults. The model was then changed to include terms for stages. The change in variance was tested for significance.

\section{Field collection of Glycaspis (S.) sp. on E. macrorhyncha and sample preparation}

Leaves bearing eggs were collected from selected trees in ENRA and MCR and brought to the laboratory for fixation for microscopy (details in "Microscopy"). Adults were reared in situ by tagging muslin bags on branches bearing galls in ENRA and MCR. The bags were checked weekly. The insect material from the bags was aspirated into Eppendorf vials containing $70 \%$ ethanol. Populations of different stages of immatures were obtained from clipped branches of E. macrorhyncha $(0.5 \mathrm{~m})$ bearing 50-60 leaves. The galls were dissected in the Charles Sturt University research laboratory (Orange campus) under a stereo binocular microscope (Wiltronics Scientific, Dissection Binocular Microscope, MS1230, Ballarat, Australia). The immatures were extracted from galls ( $n=50$ galls for each developmental stage) using a fine tipped camel hair brush. They were immediately fixed in either $70 \%$ ethanol or $2.5 \%$ glutaraldehyde in $1 \mathrm{M} \mathrm{PO}_{4}$ buffer for microscopy.

First to fifth instars (each stage $n=10)$ and adults ( $\hat{0} n=5$; q $n=5$ ) of $G$. (S.) sp. on E. macrorhyncha were prepared for permanent mounting by boiling in $95 \%$ ethanol for $5 \mathrm{~min}$ and by transferring to warm $10 \% \mathrm{KOH}$ solution $\left(\sim 60^{\circ} \mathrm{C}\right)$ until they turned translucent. These specimens were rinsed in $10 \%$ acetic acid and mounted in dibutyl-phthalate xylene (DPX).

Developmental stages of galls were ascertained by collecting randomly 450 galls of apparently different growth stages. These galls were slit along the median axis using a razor blade and the occupying immature stage was extracted. Based on the developmental stage of the extracted immatures, each gall was age categorized. Developmental stages of galls were thus determined and processed for microscopy ( $n=150$ for light, $n=150$ for electron) and morphometric measurements $(n=150)$.

\section{Microscopy}

To determine changes caused by egg deposition and immature feeding in E. macrorhyncha leaves, segments bearing eggs and developmental stages of galls were processed for observations in light and electron microscopy.

\section{Light microscopy}

Segregated leaf tissues bearing eggs and gall tissues of each developmental stage $(n=30)$ (details in "Field collection of Glycaspis (S.) sp. on E. macrorhyncha and sample preparation") were fixed in FAA [formalin, ethanol (95\%), glacial-acetic acid, distilled water - $10,50,5,35 \mathrm{ml}$, making up to $100 \mathrm{ml}$, followed by processing through alcohol series $(30,50,70,80,90$, $100 \%$, each change $12 \mathrm{~h}$ ), histolene and paraffin-wax embedding at $65^{\circ} \mathrm{C}$. The wax-embedded tissues were sectioned at $8 \mu \mathrm{m}$, deparaffinized in histolene, contrasted with either $1 \%$ toluidine blue (in $1 \%$ aqueous-borax solution) or $1 \%$ aqueous-acid fuchsin (to contrast stylet sheaths) and mounted in DPX. Micrographs were made in a photomicroscope (BX-51, Olympus Optical Co., Ltd, Tokyo, Japan).

\section{Electron microscopy}

Gall tissues of each developmental stage $(n=30)$ were fixed in $2.5 \%$ glutaraldehyde in $0.1 \mathrm{M} \mathrm{PO}_{4}$ buffer $(12 \mathrm{~h})$ and washed twice in $0.1 \mathrm{M} \mathrm{PO}_{4}$ buffer (15 min each wash). Similar fixation was done for leaf segments $\left(1 \mathrm{~mm}^{2}\right)$ bearing eggs. The samples were post fixed in $1 \% \mathrm{OsO}_{4}$ in $0.1 \mathrm{M} \mathrm{PO}_{4}$ buffer for $12 \mathrm{~h}$, washed with $0.1 \mathrm{M} \mathrm{PO}_{4}$ buffer twice as above and dehydrated in a graded alcohol series $(25-100 \%)$. The dehydrated material was infiltrated with epoxy resin $(25 \%-6 \mathrm{~h} ; 50 \%-12 \mathrm{~h}, 75 \%-6 \mathrm{~h}, 100 \%$ $-6 \mathrm{~h}, 100 \%-12 \mathrm{~h}$ ), embedded in $100 \%$ freshly prepared resin and polymerized at $60^{\circ} \mathrm{C}$. The embedded material was sectioned using glass knives at $100-120 \mathrm{~nm}$ (semi-fine sections) for light microscopy and at $60 \mathrm{~nm}$ (fine sections) for transmission-electron microscopy in an ultramicrotome (EM UC7, Leica ${ }^{\circledR}$, Mannheim, Germany). The semi-fine sections were contrasted with $1 \%$ toluidine blue dissolved in $1 \%$ aqueous borax solution and photographed in an Olympus BX-51 microscope. The fine sections mounted on copper grids were contrasted with uranyl acetate and lead citrate and viewed in a TEM $\left(2100-\mathrm{Cx}, \mathrm{JEOL}^{\circledR}\right.$, Tokyo, Japan) at $200 \mathrm{kV}$.

For scanning electron microscopy, adults $(n=5)$ and immatures ( $n=5$ of each developmental stage) of $G$. (S.) sp. on E. macrorhyncha were prepared as described in the preceding paragraph, 
except that the time for $2.5 \%$ glutaraldehyde fixation was $4 \mathrm{~h}$. The fixed materials were dehydrated as described earlier, followed by cleaning in a sonicator Branson $^{\circledR}$ 2510, Danbury, Connecticut, USA) for 5 min and critical-point dried in a CPD (030, Bal-Tec $\mathrm{AG}^{\circledR}$, Schalksmühle, Germany). The materials were coated with gold in a sputter coater (SC7620, Quorum Technologies Limited, Kent, UK) and viewed in an SEM (S-4500, Hitachi Scientific Instruments, Tokyo, Japan) at $5 \mathrm{kV}$.

\section{Gall morphometrics}

Galls were segregated ( $n=30$ for each stage) following the method described in "Microscopy" above. Length $(\alpha)$, width $(\beta)$ and height $(\gamma)$ of galls and gall-wall thickness (wt) were measured (Fig. 1). Gall-morphometric data were analysed using canonical variates. Analysis was carried out using GenStat ${ }^{\mathrm{TM}}$. The filamentous material occurring in galls, secreted by immatures was tested for its chemistry following White (1972).

\section{RESULTS}

Galls, as near spheres, manifest on the adaxial sides of leaves of E. macrorhyncha (Fig. 2). Ostioles of galls are plugged with lerp material (Fig. 1) which extends into the gall cavity as a ball of filamentous material (Fig. 3), secreted by the immature stages through their anal pore fields located on the terminal abdominal segments (Fig. 4). This filamentous material responded positively to I-KI test (White, 1972) indicating that it contains starch.

Occasionally, two neonate immatures can settle in close proximity to each other and induce galls, which results in apparently "single" galls, but with two well-defined gall chambers. Field observations indicate that birds cut open mature galls to feed on the filamentous sugary material and perhaps the inhabiting immatures (Fig. 2).

\section{Glycaspis (S.) sp. on E. macrorhyncha}

Life cycle

Immatures (Figs 5-9) live in galls and emerge as adults (Figs 10-11). The number of adults and immatures from MCR obtained in 2013-2014 were greater than those obtained from ENRA in 2012-2013. Two generations were completed in 2013-2014. Over this period, 400 leaves were sampled, which bore from a minimum of one gall/ leaf to a maximum of eight/leaf; the average being four/

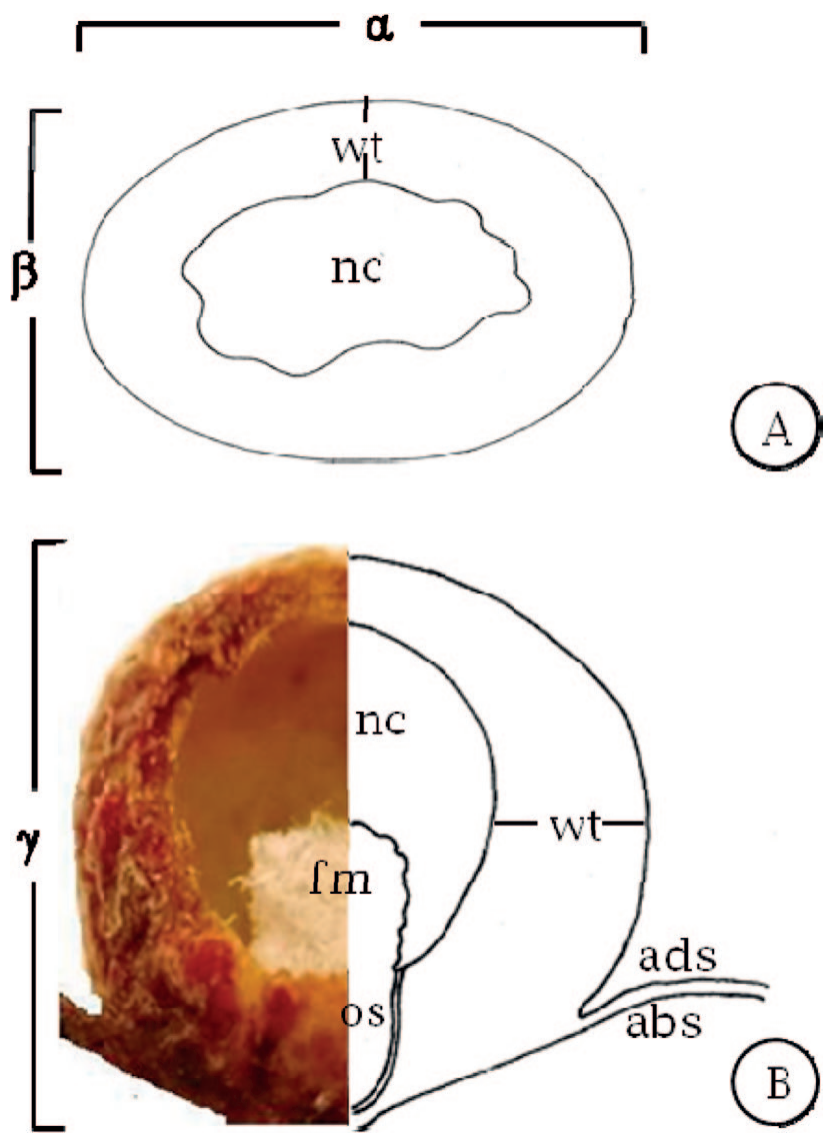

Fig. 1. Schematic representation of the gall of Glycaspis (Synglycaspis) sp. (third instar) on Eucalyptus macrorhyncha. A median cross-sectional view at the widest point ( $\alpha-$ length; $\beta$ - width; wt - wall thickness; nc - nymphal chamber); B - median-longitudinal sectional view ( $\mathrm{\gamma}$ - height; $\mathrm{wt}$ - wall thickness; fm - filamentous material; nc - nymphal chamber; os - ostiole; ads - adaxial leaf surface; abs - abaxial leaf surface) (not to scale).

leaf. Eggs $(n=30)$ hatched in $14 \mathrm{~d}$ and the average time taken by the first $(n=10)$, second $(n=10)$ and the third ( $n$ $=10)$ instars to complete each moult was $10 \pm 3 \mathrm{~d}$ and by the fourth $(n=10)$ and fifth $(n=10)$ instars was $15 \pm 3 \mathrm{~d}$. Few adult males and females were available in early March 2014. A summary of the phenology is as follows: newly

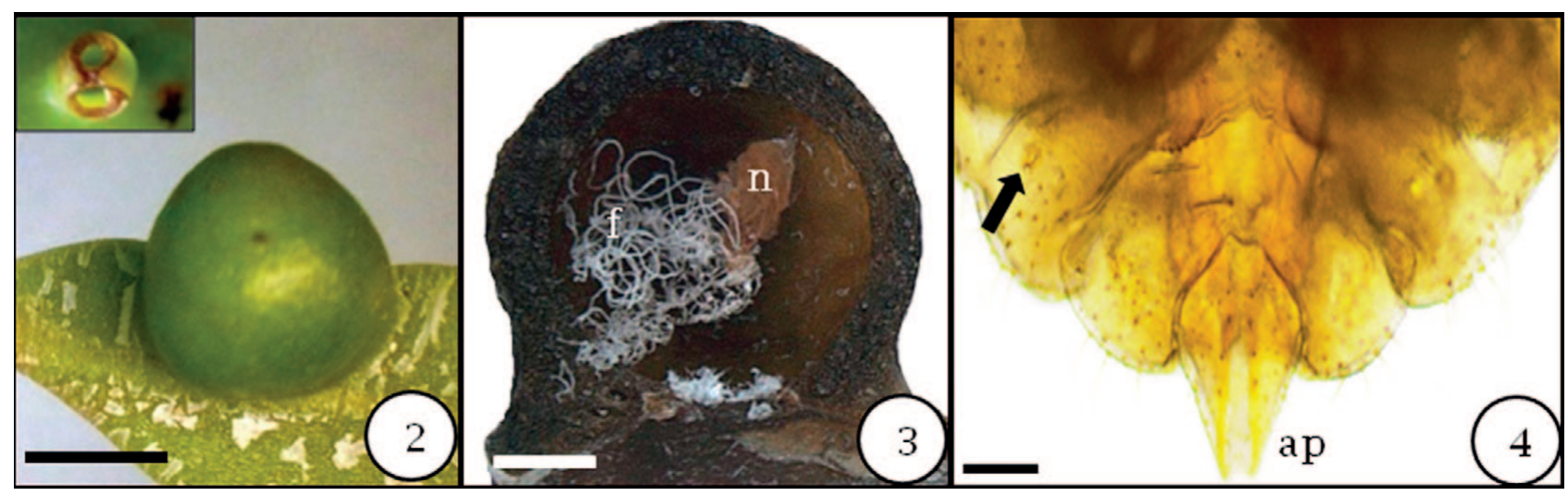

Figs 2-4. Glycaspis (Synglycaspis) sp. on E. macrorhyncha. 2 - nearly complete, spherical gall induced by the second instar (bar = $5 \mathrm{~mm}$ ). Inset: a gall of a second instar cut open possibly by a bird; 3 - median vertical-longitudinal section of a gall induced by a third $\operatorname{instar}(\mathrm{n})$ with sugary filaments (f) (bar $=1 \mathrm{~mm}) ; 4$ - terminal abdominal segments of second instar $(\mathrm{bar}=1 \mu \mathrm{m})$; arrow - wax-secreting pore; ap - anal pore from which the instars secrete filamentous sugary material. 


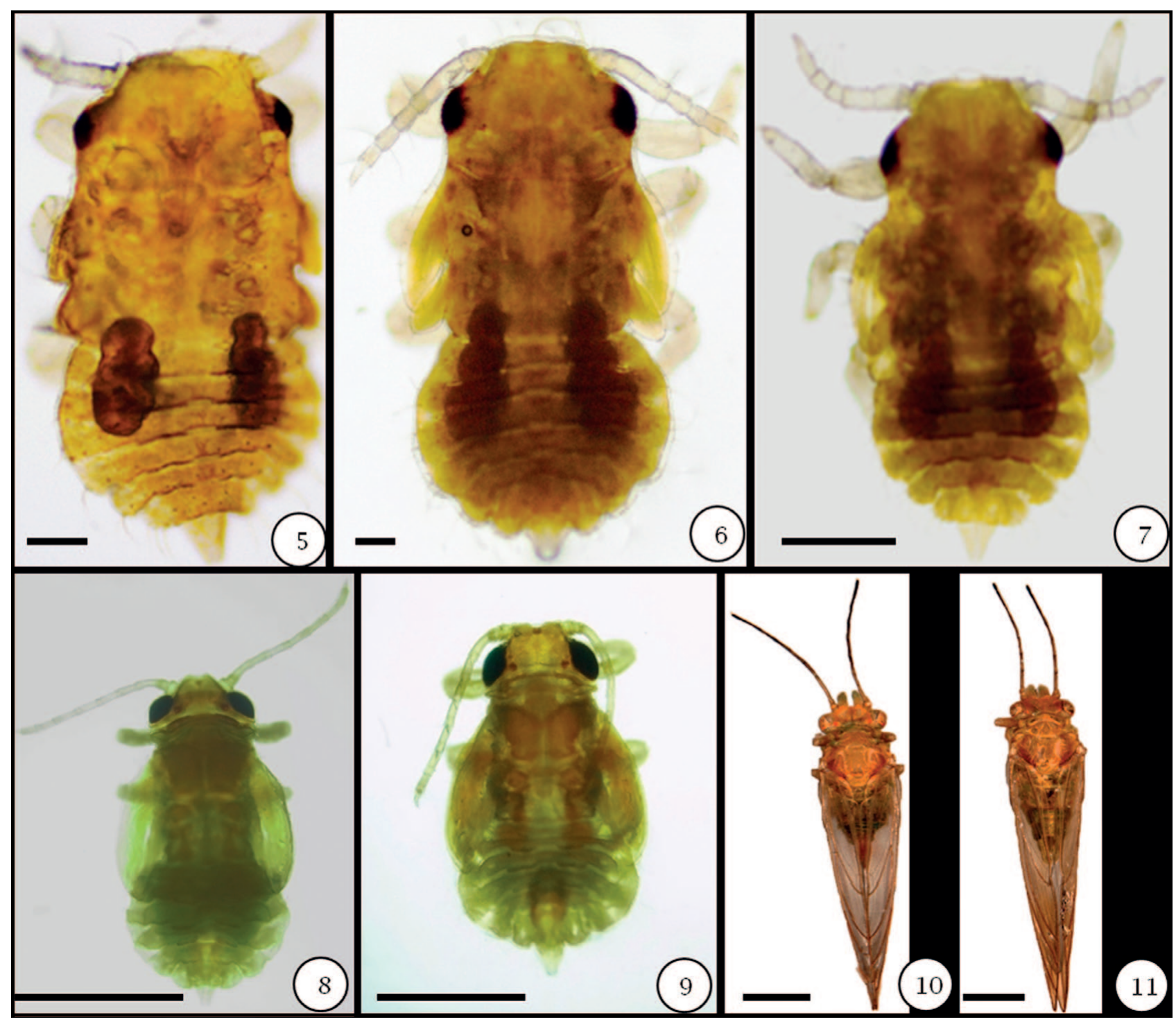

Figs 5-11. Developmental stages of Glycaspis (Synglycaspis) sp. on E. macrorhyncha. 5 - first instar (bar $=100 \mu \mathrm{m}) ; 6-\mathrm{second}$ instar $($ bar $=100 \mu \mathrm{m}) ; 7-$ third instar $($ bar $=500 \mu \mathrm{m}) ; 8-$ fourth instar $($ bar $=1 \mathrm{~mm}) ; 9-$ fifth instar $($ bar $=1 \mathrm{~mm}) ; 10-$ adult male $($ bar $=1 \mathrm{~mm}) ; 11-$ adult female $(\mathrm{bar}=1 \mathrm{~mm})$.

emerged adults mate in late spring (mid-late November) and oviposition coincides with the growth of new foliage at the onset of summer (December); the immatures and galls develop over summer and adults emerge in late summerearly autumn (February-March). These adults oviposit on new foliage. Gall development occurs slowly through winter (June-August) and speedily in spring (September-November); adults from this winter-spring generation emerge towards the end of spring-early summer (late November). Population numbers for eggs, immatures and adults were plotted against sampling time and polynomials (second order) fitted. Significant differences were found between the polynomials (Fig. 12; $\mathrm{df}=23,24 ; \mathrm{F}=58.4 ; p<0.001$ ). In October 2013, the third, fourth and fifth instars were present. The numbers of these life stages declined with time; the numbers of first and second instars were low in October and increased with time until January, showing bivoltinism in their life cycle.

\section{Sensory structures}

Antenna in adults is filiform (Fig. 13) and is longer in females $(1.72 \pm 0.10 \mathrm{~mm} ; n=8)$ than in males $(1.42 \pm 0.10$, $n=8)$. The antenna comprises the scape $(100 \mu \mathrm{m}$ wide $\times$ $85.7 \mu \mathrm{m}$ long $)$, the pedicel $(64.2 \mu \mathrm{m}$ wide $\times 57 \mu \mathrm{m}$ long $)$ and eight flagellomeres. The number of flagellomeres on the antennae of the first, second and the third instars are three, five and six, respectively, and vary in lengths (170$1700 \mu \mathrm{m})$. The number of flagellomeres on the antennae of the fourth and fifth instars is seven. The terminal segment of the adult antenna includes two unequal terminal setae (the shorter of the two $\sim 12 \mu \mathrm{m}$ long, $\sim 8.5 \mu \mathrm{m}$ basal width, $\sim 5 \mu \mathrm{m}$ tip width; the longer of the two $\sim 85 \mu \mathrm{m}$ long, $\sim 12 \mu \mathrm{m}$ basal width, $\sim 3.5 \mu \mathrm{m}$ tip width). The terminal segment of the antenna of the immatures also includes two unequal terminal setae (Fig. 14). All stages of immatures bear trichoid sensilla that occur close to the apex of each segment (Fig. 14), whereas the adult antennae include trichoid sensilla ( $23 \mu \mathrm{m}$ long) distributed all over (Fig. 15). The 


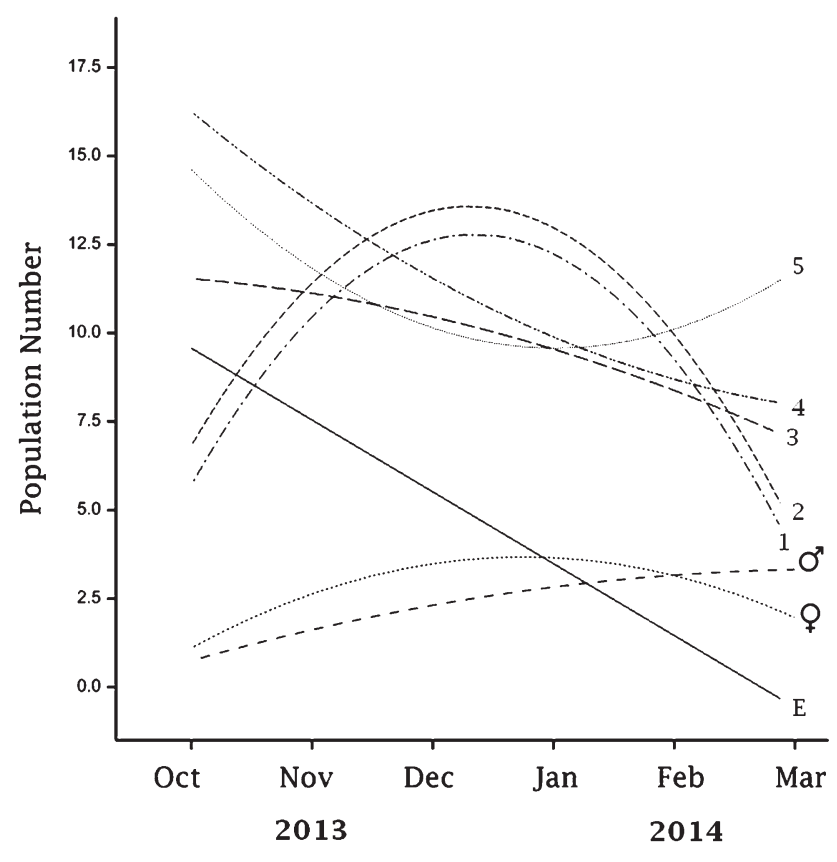

Fig. 12. Population dynamics of Glycaspis (Synglycaspis) sp. on Eucalyptus macrorhyncha ( $n=400$ leaves) in 2013-2014. (-) eggs [E]; (---) first instar [1]; (---) second instar [2]; (--) third

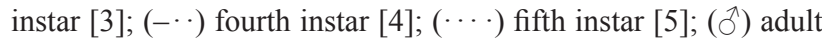
males; ( $($ ) adult females.

adult antenna includes a rhinarium on flagellar segments 2 , 4, 6 and 7 in subapical positions (Fig. 15; inset).

Mouthparts of adults include a postclypeus and labium $(\sim 500 \mu \mathrm{m})$ (Fig. 16). Four equidistally distributed sensilla occur on either side of the labium (Fig. 17). The external edges of the mandibles include eight teeth (Fig. 18).

\section{Oviposition, host response}

Gravid females oviposit only on the abaxial surfaces of tender leaves. The sclerotized, pointed dorsal and ventral valvulae $(\sim 100 \mu \mathrm{m} ; n=3)$ are enclosed by the proctiger dorsally and subgenital plate ventrally (Fig. 19). The proctiger is short, broad and concave dorsally, with a round tip, whereas the subgenital plate is short with a triangular tip. The female terminalia are densely sculptured with several scale-like spinules, each endowed with long $(\sim 180 \mu \mathrm{m})$ and short $(\sim 6 \mu \mathrm{m})$ spines arranged in a regular fashion (Fig. 20). Using the pointed, sclerotized tip of the ventral valvulae, the gravid female punctures the abaxial surface of the leaves of E. macrorhyncha to deposit one egg in each hole. Usually 3-6 eggs occur in close proximity. A mature egg is ovoid $(0.4 \pm 0.15 \mathrm{~mm}$ long; $0.2 \pm 0.15 \mathrm{~mm}$ wide; $n=10)$ surmounted by an elongate pedicel $(0.15 \pm$ $0.05 \mathrm{~mm}$ long; $0.03 \pm 0.01 \mathrm{~mm}$ wide; $n=30$ ) (Fig. 21). On maturation, the pedicel bends in such a way that the egg comes close to the leaf surface. The egg dehisces along its vertical axis (Fig. 21) eclosing the neonate immature, which settles on a stomatal aperture.

The oviposition puncture produced by the gravid female to deposit the egg is narrow and the embedded pedicel of the egg is thin. The cells around the egg pedicel present varying profiles. Some are degenerated and bear thick walls. Secondary metabolic compounds completely fill intercellular spaces. A few others appear dynamic and include prominent nuclei and dense cytoplasm (Fig. 22). The inserted egg pedicel extends into the lower palisade mesophyll cells along the abaxial surface, since the leaves of E. macrorhyncha are isobilateral with palisade cells occurring along both the upper and lower sides of the leaf. Insertion of the pedicel stimulates the epidermal cells to grow around the pedicel, resulting in a collar-like growth (Fig. 23). Subcellular alterations occur in adjacent cells. Epidermal and palisade cells show hypertrophy and hyperplasia (Fig. 23). The epidermal cells adjacent to the egg pedicel divide randomly. Nearby cells divide vertically, whereas the cells occurring a little farther away divide horizontally contributing to collar-like growth. The deposition of the egg on the leaves of E. macrorhyncha stresses the leaf tissues in such a way that the mesophyll cells occurring away from the egg pedicel turn metaplastic; they include hypertrophied nuclei, numerous small and large vacuoles and a few vacuoles including subcellular debris. These cells bear unevenly thickened walls due to irregular deposition of cell-wall materials (Fig. 24). These cells nourish the embryo via the egg pedicel. With ageing and with the egg ready to discharge the neonate immature, the mesophyll cells turn hypertrophied and become elongate in the horizontal axis and accumulate intense levels of phenolic inclusions (Fig. 25).

\section{Galls on E. macrorhyncha}

\section{Development}

Neonate immatures settle on stomatal apertures along the abaxial leaf surface. They feed on the lower palisade tissues by inserting their stylet $(0.37 \pm 0.10 \mathrm{~mm} ; n=10)$. This action stimulates the leaf site to cave in, forming a shallow pit $\left(1.6 \times 1.5 \times 1.2 \mathrm{~mm}^{3}\right)($ Fig. 26$)$. In this pit, the neonate immature settles snugly. The first instar secretes sugary material, which spreads as a thin cover over the immature insect (Fig. 27). In 8-9 d, the pit develops into a thickened organ consisting of 50-60 layers of small, isodiametric, closely packed parenchyma cells. This development differs from the normal leaf differentiation, which would include a maximum of 12-15 layers of mesophyll, with palisade tissue distributed along either epidermis. In the thickened "gall", parenchyma cells occurring close to the upper epidermis include densely staining materials, viz., secondary metabolic compounds. Oil glands do not undergo any modification (Fig. 28). At the feeding site, the epidermal cells turn hyperplastic, resulting in a multi-layered epidermis. Cells adjacent to the stomatal aperture where the stylet insertion occurs include prominent nuclei and intense cytoplasm. The stylet terminates in undifferentiated parenchyma, which constitutes a neoformed meristem made of concentrically arranged actively dividing cells. The first instar feeds from this tissue. The metabolic effect caused by this feeding action spreads towards the interior of the gall in a radiating pattern. The pattern of actively dividing cells stretches towards the abaxial epidermis with cells showing no division activity. Parenchyma cells adjoining the vascular trace show a different response accumulating secondary 


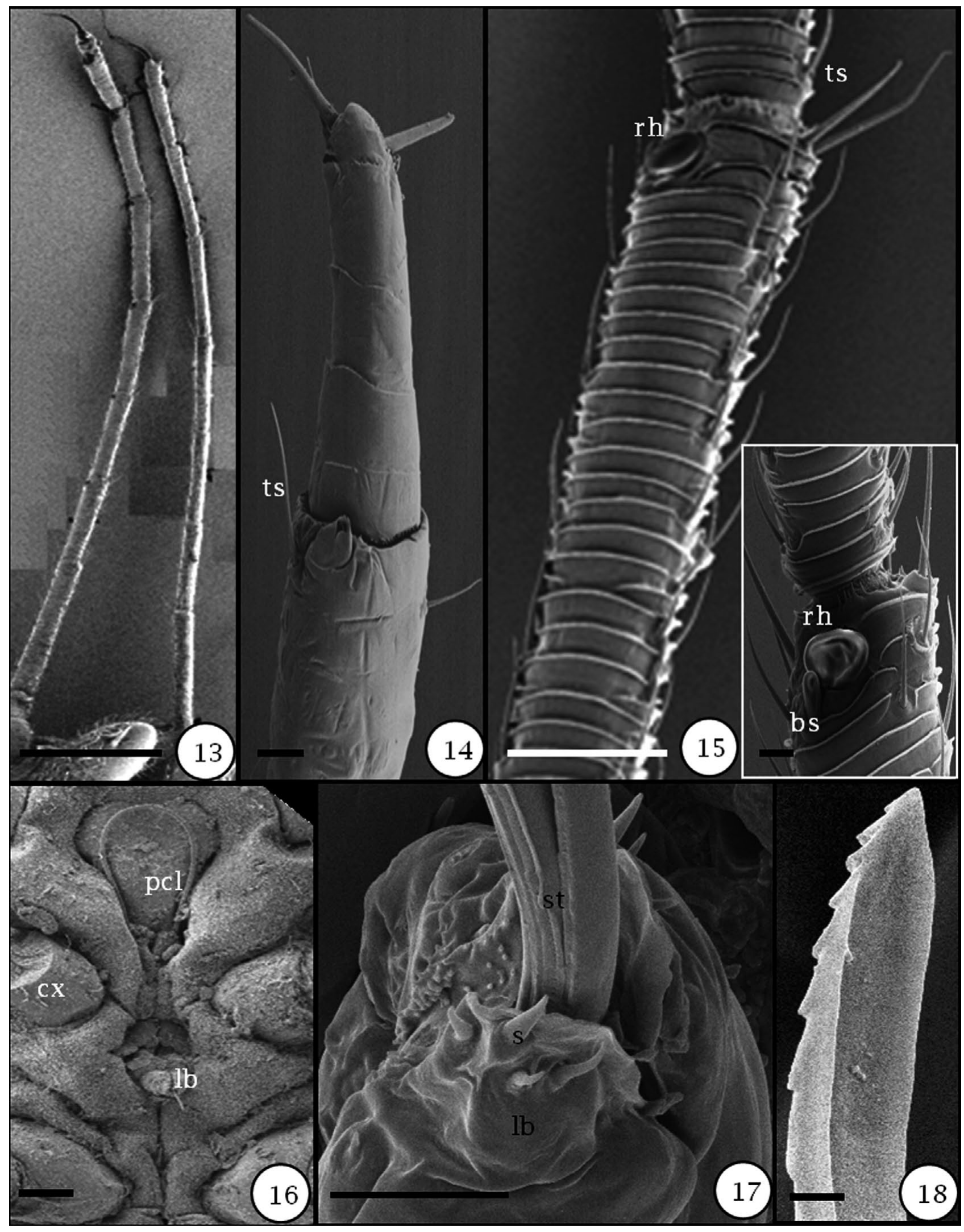

Figs 13-18. Sensilla on the antennae and mouthparts of Glycaspis (Synglycaspis) sp. on E. macrorhyncha. 13 - filiform antenna, adult $($ bar $=500 \mu \mathrm{m}) ; 14-$ antenna, third instar: ts, trichoid sensillum at the base of flagellomere $($ bar $=30 \mu \mathrm{m}) ; 15-$ antenna, adult: ts - trichoid sensilla; rh - rhinarium (bar $=50 \mu \mathrm{m})$; inset - antenna, adult, bs - basiconic sensillum; rh - rhinarium $(\mathrm{bar}=10 \mu \mathrm{m})$; 16 - mouthparts, second instar, lb - labium; cx - coxa; pcl - postclypeus (bar $=100 \mu \mathrm{m}) ; 17$ - mouthparts, second instar: $\mathrm{s}-$ sensilla on the extended labium; $1 \mathrm{~b}$ - labium; st - stylet ( $\mathrm{bar}=10 \mu \mathrm{m}) ; 18$ - mouthparts, second instar, serrate margin of the mandibular stylet $($ bar $=1 \mu \mathrm{m})$. 


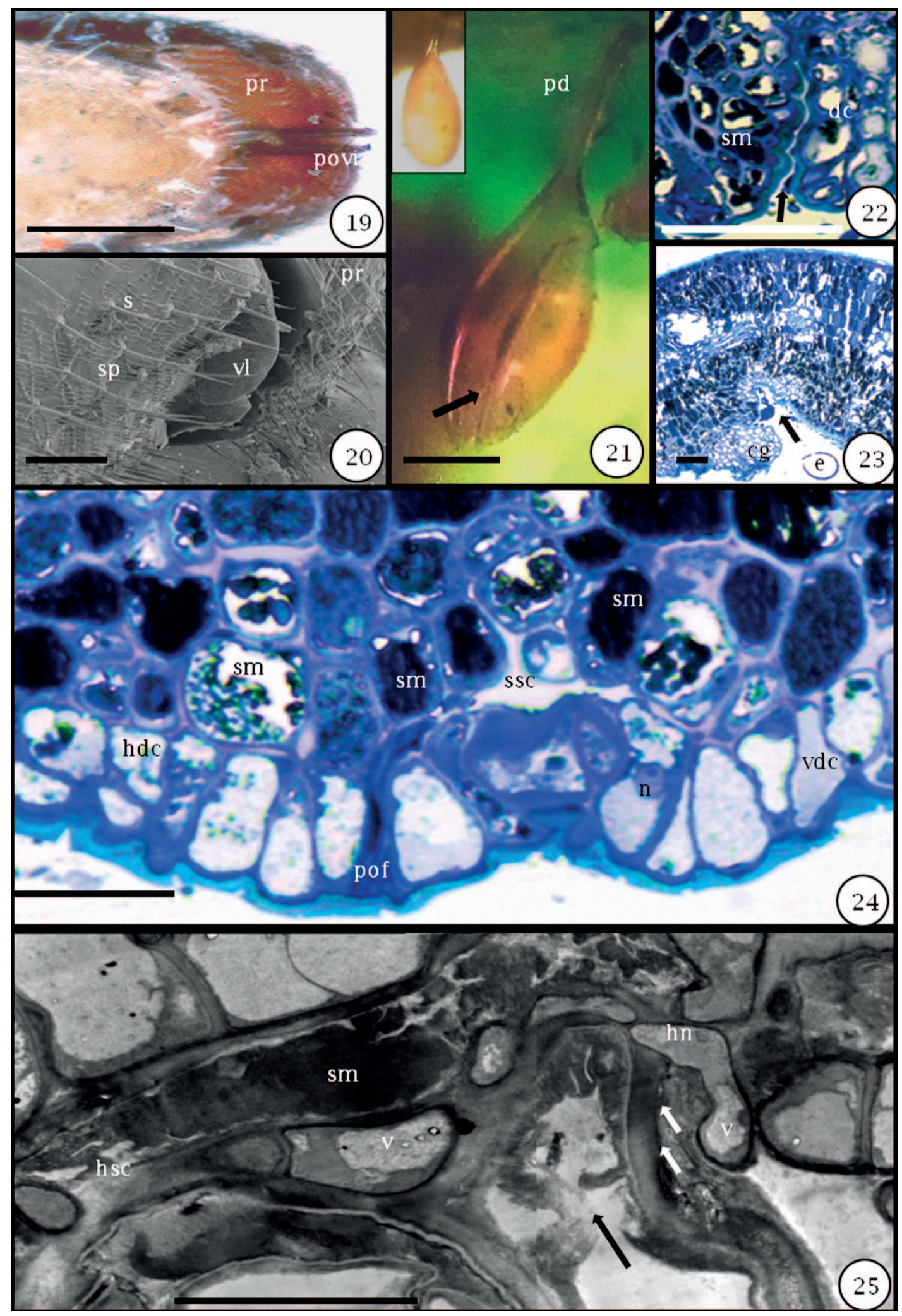

Figs 19-25. Ovipositor, eggs of Glycaspis (Synglycaspis) on E. macrorhyncha and responses in E. macrorhyncha leaf. 19-Ovipositor: povi, pointed ovipositor tip; $\mathrm{pr}$ - proctiger $(\mathrm{bar}=100 \mu \mathrm{m}) ; 20$ - setae distribution on the subgenital plate: $\mathrm{s}-\mathrm{seta}$; $\mathrm{pr}-\mathrm{proctiger} ; \mathrm{sp}-$ subgenital plate; $\mathrm{vl}$ - valve $(\mathrm{bar}=50 \mu \mathrm{m}) ; 21$ - dehisced egg: pd - pedicel; arrow - line of dehiscence; inset, undehisced egg $($ bar $=10$ $\mu \mathrm{m}) ; 22-E$. macrorhyncha leaf (cross-section): arrow - pedicel insertion point; sm - secondary-metabolic inclusions; dc - dynamic cells $(\mathrm{bar}=100 \mu \mathrm{m}) ; 23-$ E. macrorhyncha leaf (oblique cross-section): e - egg; cg - collar-like growth; arrow - pedicel insertion point $($ bar $=100 \mu \mathrm{m}) ; 24-$ E. macrorhyncha leaf (cross-section): ssc - sub-stomatal chamber; sm - secondary metabolic inclusions; vdc - vertically dividing cells; hdc - horizontally dividing cells; $\mathrm{n}$ - nucleus; pof - polymerized oviposition fluid (bar $=100 \mu \mathrm{m})$; 25 - E. macrorhyncha leaf (cross-section): hsc - horizontally stretched cells; sm - secondary metabolic inclusions; v - vacuole; hn hypertrophied nucleus; closed arrow - egg-pedicel insertion point; open arrows - irregular deposition of cell wall material $(\mathrm{bar}=5 \mu \mathrm{m})$. 


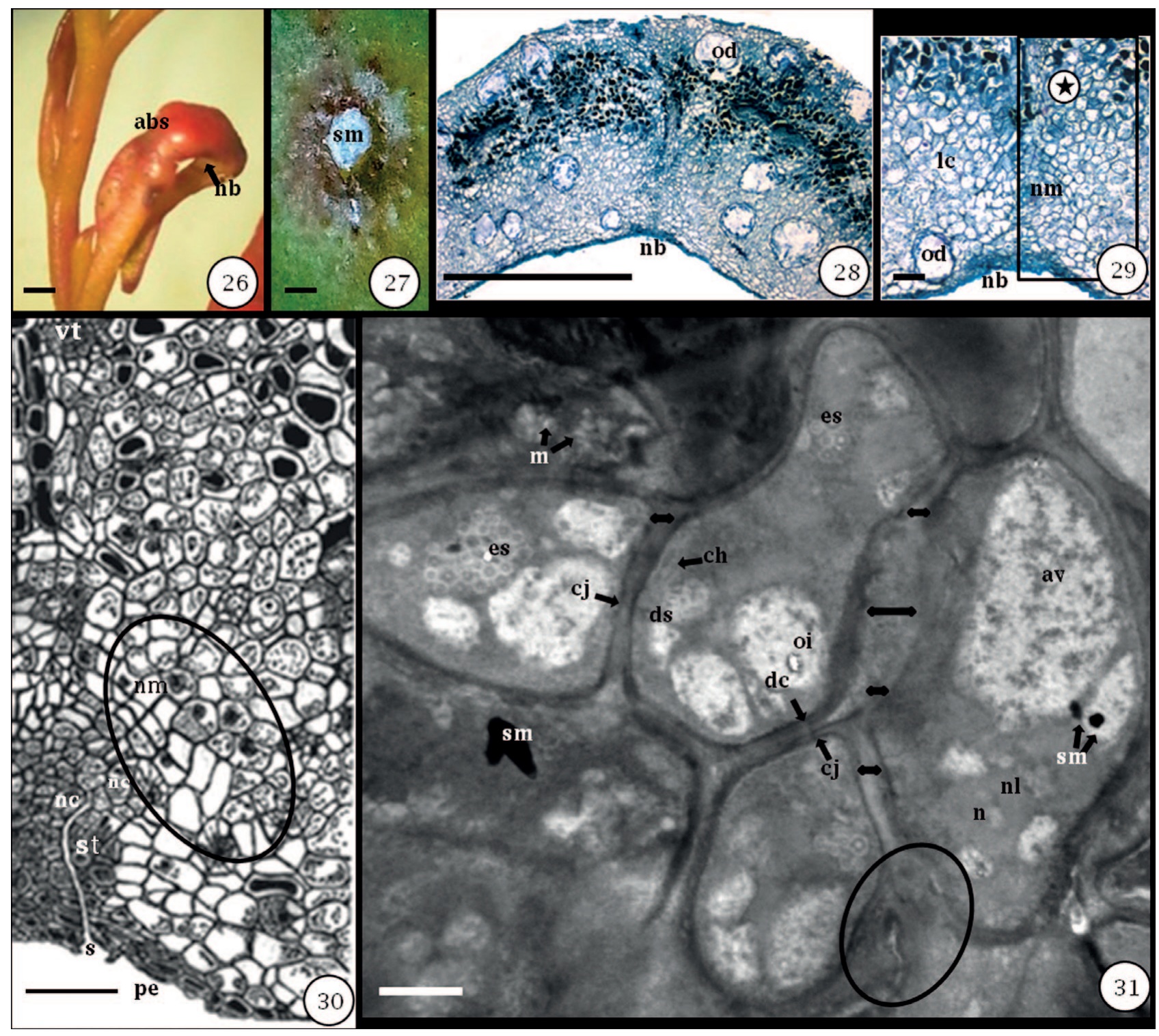

Figs 26-31. Gall (8-9 d old) induced by the first instar of $G$. (S.) sp. on E. macrorhyncha. 26 - developing gall on a tender leaf: abs - abaxial surface; $\mathrm{nb}$ - pit (bar $=1 \mathrm{~mm}) ; 27$ - pit of the first instar covered by a thin film of sugary material $(\mathrm{sm})(\mathrm{bar}=1 \mathrm{~mm}) ; 28-E$. macrorhyncha leaf (cross-section): od - oil duct; $\mathrm{nb}$ - pit (bar =1 mm); 29 - details of the pit from Fig. 28: nb - pit; od - oil duct; lc - lysogenous cavity; $\mathrm{nm}$ - neoformed meristem; asterisk - radiating pattern of feeding action; framed region is shown enlarged in Fig. $30($ bar $=100 \mu \mathrm{m}) ; 30$ - framed region in Fig. 29: nc - nutritive cells; vt - vascular trace; st - stylet track; s - stomatal aperture; pe proliferating epidermal cells; circled area, dividing cells $(\mathrm{bar}=100 \mu \mathrm{m}) ; 31-$ E. macrorhyncha leaf (cross-section): es - endosome; ch - chloroplast; sm - secondary metabolic inclusion; av - autophagic vacuole; cj - cell junctions; $\mathrm{m}$ - mitochondrion; dc - desmosomal condensation; oi - oil inclusion; $\leftrightarrow-$ dissolved middle lamella; circled area, stylet path $(\mathrm{bar}=1 \mu \mathrm{m})$.

metabolic compounds; the cells are inactive. Gall induction signals flow towards the abaxial epidermis directing cell number increment and thus contributing to gall growth (Figs 29, 30). The erstwhile mesophyll cells, now developed into gall tissue, away from the feeding site, include lysogenous cavities, due to extensive stretching and cell multiplication in the vicinity. In high likelihood, these tissues suffer moisture stress (Fig. 31).

The lower mesophyll parenchyma tissue, from which the insect feeds, includes closely packed, nearly isodiametric cells with dense cytoplasm. The walls of proximal cells occurring along the same axis of the wall appear dilated due to stylet penetration and are loosened with dissolved middle lamellae. Adjacent cells at this site display active inter- cellular communication with prominent gap junctions with electron dense plasmodesmatic strands. On either side of the gap junctions, desmotubular condensations occur. The cytoplasm of the nutritive cells is dense and includes several large and small vacuoles. The larger vacuoles include cell debris, oil droplets and secondary metabolic inclusions. Chloroplasts appear disfigured with degenerated thylakoid system. Endosomes appear prominently (Fig. 31).

When the first instar moults into the second instar, the gall achieves its near final shape $\left(3.6 \times 3.0 \times 3.0 \mathrm{~mm}^{3} ; n\right.$ $=30$ ) (Fig. 32). The gall at this stage of development includes an ostiole $(0.5 \times 0.5 \mathrm{~mm} ; n=10)$, which is plugged by filamentous sugary material (Fig. 33). The 8-9 d old gall is ovate in cross section, consisting of 35-40 layers of 


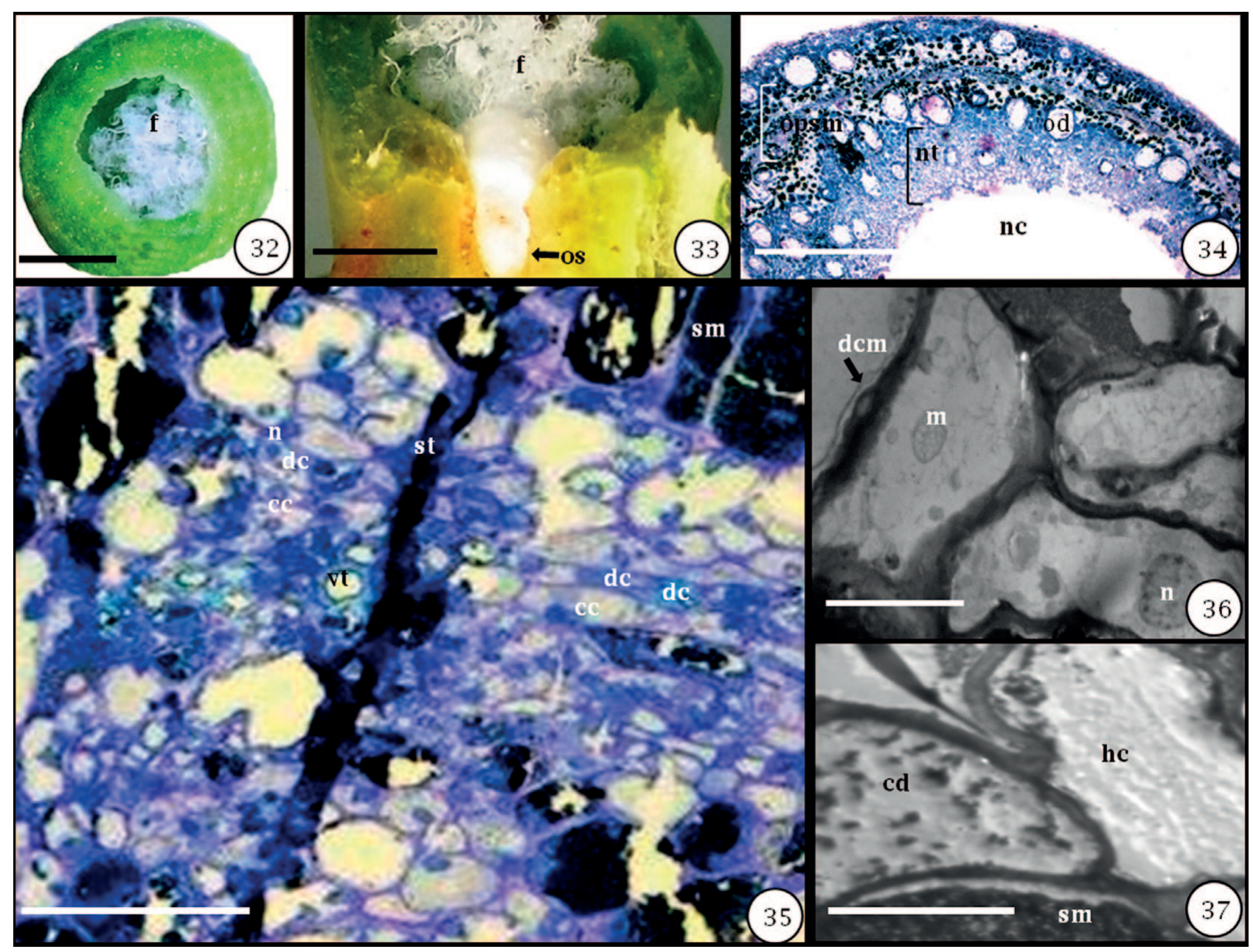

Figs 32-37. Gall (10-20 d old) induced by the second instar of $G$. (S.) sp. on E. macrorhyncha. 32 - cross-sectional view: f - sugary filaments $(\mathrm{bar}=5 \mathrm{~mm}) ; 33$ - median longitudinal sectional view: ostiole (os) plugged by sugary filaments $(\mathrm{f})(\mathrm{bar}=1 \mathrm{~mm}) ; 34-$ cross-sectional view: od - oil duct; nt - nutritive tissue; nc - nymphal chamber; opsm - outer parenchyma with secondary metabolic inclusions (bar = $1 \mathrm{~mm}$ ); 35 - cross-sectional view, 10-15 d old gall, nutritive tissue including active and dynamic parenchyma cells with prominent nuclei: st - stylet track; vt - vascular trace; sm - secondary metabolic inclusion; cc - condensed cytoplasm; $\mathrm{n}$ nucleus; $\mathrm{dc}$ - degenerating cells $(\mathrm{bar}=500 \mu \mathrm{m}) ; 36$ - cross-sectional view, 15-20 d old gall, older nutritive tissue showing exhausted parenchyma: $\mathrm{n}$ - nucleus; $\mathrm{m}$ - mitochondrion; $\mathrm{dcm}$ - distended cell membrane (bar $=10 \mu \mathrm{m}$ ); 37 - cross-sectional view, 15-20 d old gall, older nutritive tissue showing exhausted parenchyma with hyaline cytoplasm (hc), secondary-metabolic inclusions (sm), cell debris $(\mathrm{cd})(\mathrm{bar}=5 \mu \mathrm{m})$.

isodiametric parenchyma cells. Oil ducts occur away from the layers of parenchyma from which the inhabiting immatures feed (Fig. 34). The second instar, similar to first instar, feeds on parenchyma, but on deeper layers because of the greater length of its stylets $(0.55 \pm 0.10 \mathrm{~mm} ; n=$ 10). The peripheral parenchyma cells include secondary metabolic inclusions (Fig. 35), which appear to restrict the immature from feeding on tissues beyond. The nutritive parenchyma divides actively and includes dynamic cell contents. The bordering cells are less active and are horizontally stretched (Fig. 35). The erstwhile nutritive cells in the galls that house the immatures ready-to-moult to the next stage include cells with wavy and thickened walls, distended cell membranes, condensed heterochromatin, hyaline cytoplasm and exhausted mitochondria with inflated and malformed cristae (Fig. 36). A few cells also include secondary metabolic compounds (Fig. 37).
The galls with the third and fourth instars are nearly spherical $\left(4.2 \times 3.5 \times 3.4 \mathrm{~mm}^{3} ; 5.6 \times 4.5 \times 4.4 \mathrm{~mm}^{3}\right.$, respectively) (Fig. 38). They consist of 25-30 layers of cells. The nutritive parenchyma cells dry and shrivel, because they are no more fed upon by the immature (Fig. 39). The immatures shift their feeding to phloem, taking an intercellular path [stylet lengths: $0.80 \pm 0.10 \mathrm{~mm}$ third instar; 0.85 $\pm 0.10 \mathrm{~mm}$ fourth instar $(n=10)$ ] (Fig. 40$)$.

During final stages of development, in galls occupied by the fifth instar $\left(6.7 \times 6.0 \times 5.6 \mathrm{~mm}^{3}\right)$, the filamentous sugary material that was plugging the ostiole becomes loose and shrinks into the gall. How this occurs without the plug dropping outside is not clear (Fig. 41). The gall shows signs of desiccation accompanied by intense accumulation of secondary metabolic compounds and crystalline druses (Fig. 42). Due to desiccation, the ostiole widens (2 $\times 2 \mathrm{~mm} ; n=10)$. Stylet length of the fifth instar is $1.00 \pm$ $0.10 \mathrm{~mm}(n=10)$. The mesophyll tissue near the vascular 


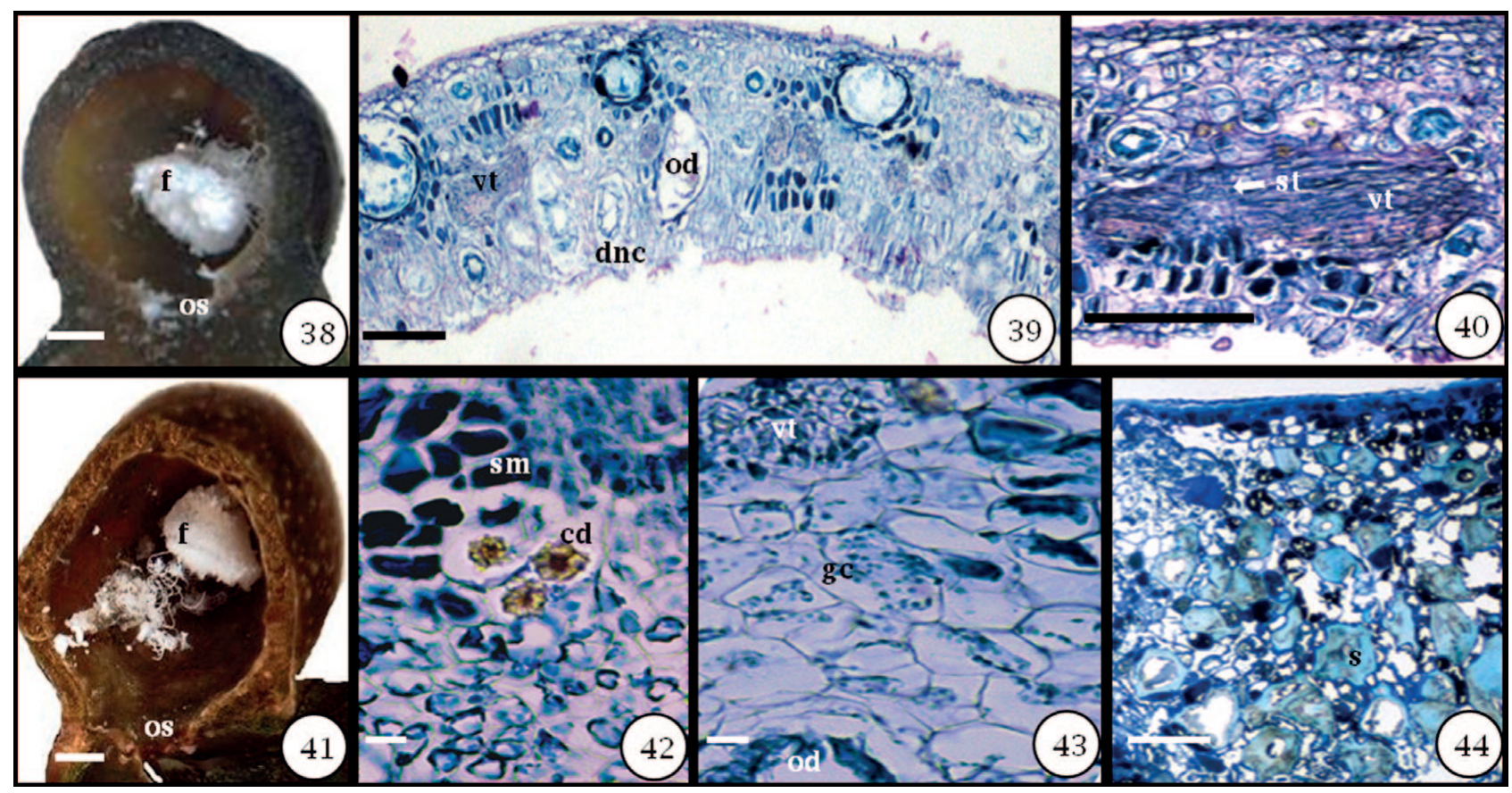

Figs 38-44. Galls induced by the third and fifth instars of $G$. (S.) sp. on E. macrorhyncha. 38-40: Gall induced by the third instar (20-30 d). 38 - median longitudinal-sectional view: $\mathrm{f}$ - sugary filaments; os - ostiole (bar $=1 \mathrm{~mm})$; 39 - cross-sectional view: dnc degenerating, shrinking nutritive cells; od - oil duct; vt - vascular trace (bar $=100 \mu \mathrm{m}) ; 40$ - cross-sectional view: st - stylet track; vt - vascular trace $(\mathrm{bar}=10 \mu \mathrm{m}) .41-44$ : Gall induced by the fifth instar $(45-60 \mathrm{~d}) .41$ - median longitudinal-sectional view: $\mathrm{f}$ - sugary filaments; os - ostiole (bar = $1 \mathrm{~mm}$ ); 42 - cross-sectional view of mesophyll parenchyma: cd - crystalline druses; sm - secondary metabolic inclusions $(\mathrm{bar}=100 \mu \mathrm{m}) ; 43$ - cross-sectional view of mesophyll parenchyma: od - oil duct; vt - vascular trace; sm secondary metabolic inclusions $(\mathrm{bar}=100 \mu \mathrm{m}) ; 44-$ cross-sectional view: $\mathrm{s}-$ sclereids $(\mathrm{bar}=100 \mu \mathrm{m})$.

bundle includes granular cytoplasm (Fig. 43). Ten-12 day old galls housing fifth instars include thick walled sclereids (Fig. 44).

Morphometrics

Length, width and height dimensions of the gall increase to about three times from the first to fifth stage gall. The

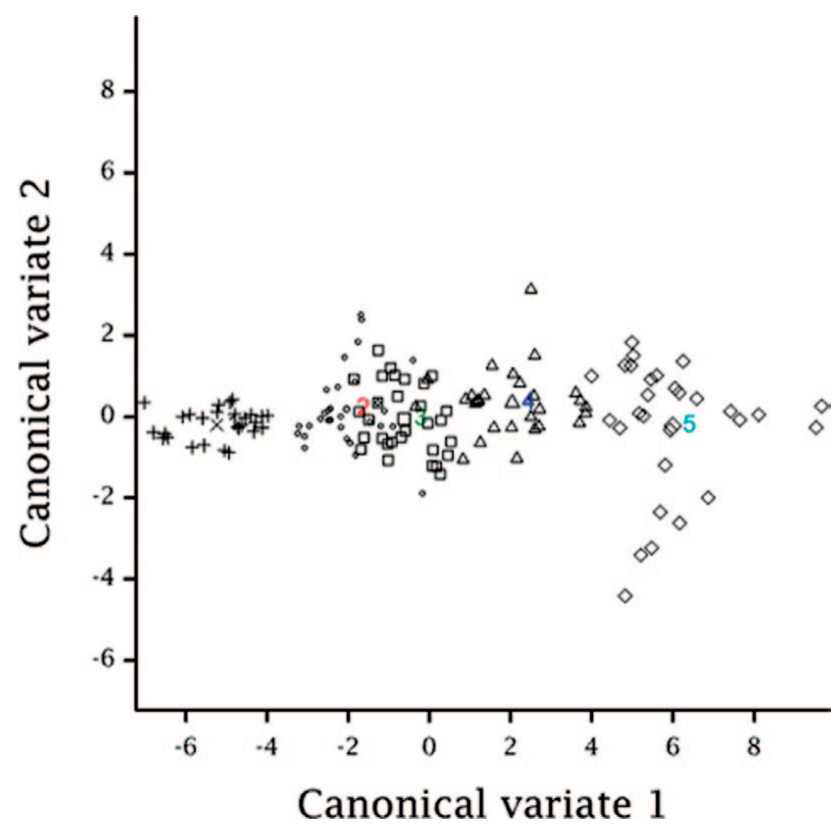

Fig. 45. Fitted and observed relationships for gall length, width, and height in relation to the developmental stages (1-5) of Glycaspis (Synglycaspis) sp. on E. macrorhyncha. canonical variates analysis of length, width and height of galls of each stage (for each stage $n=30$ ) shows "width" as the most substantial variable between different stages of galls (Fig. 45). The canonical variant shows 99.6\% variation. The regression analysis of gall thickness and other parameters (length, width and height) shows non-signifi-

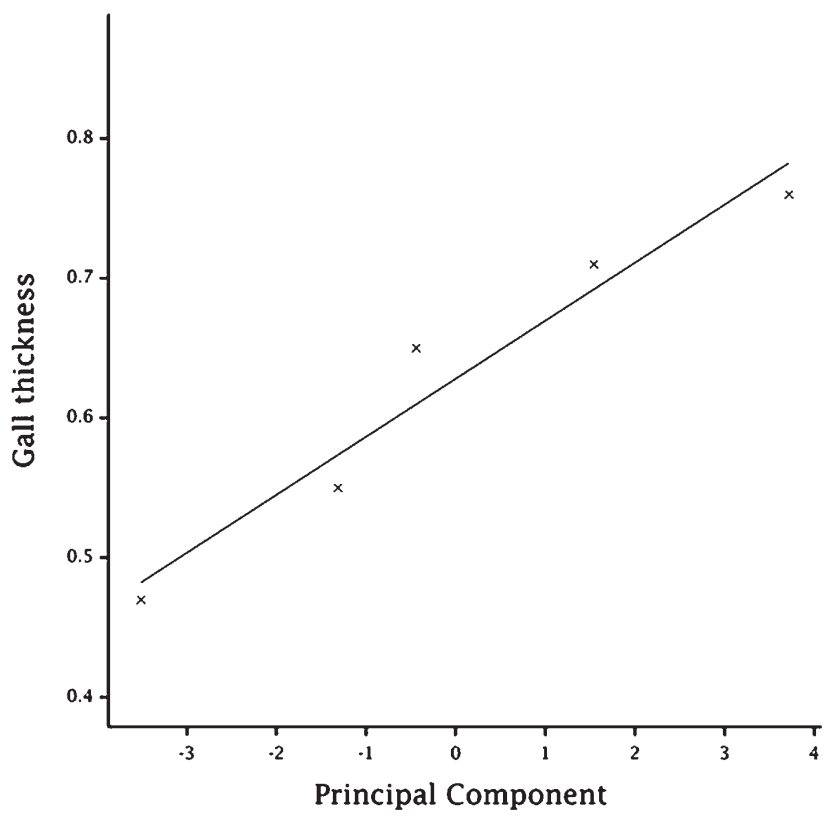

Fig. 46. Fitted and observed relationships for gall morphometrics. $x-\mathrm{C} 1$ (gall length, gall width, and gall height). $\mathrm{y}-$ thickness of galls of different developmental stages (in $\mathrm{mm}$ ). 


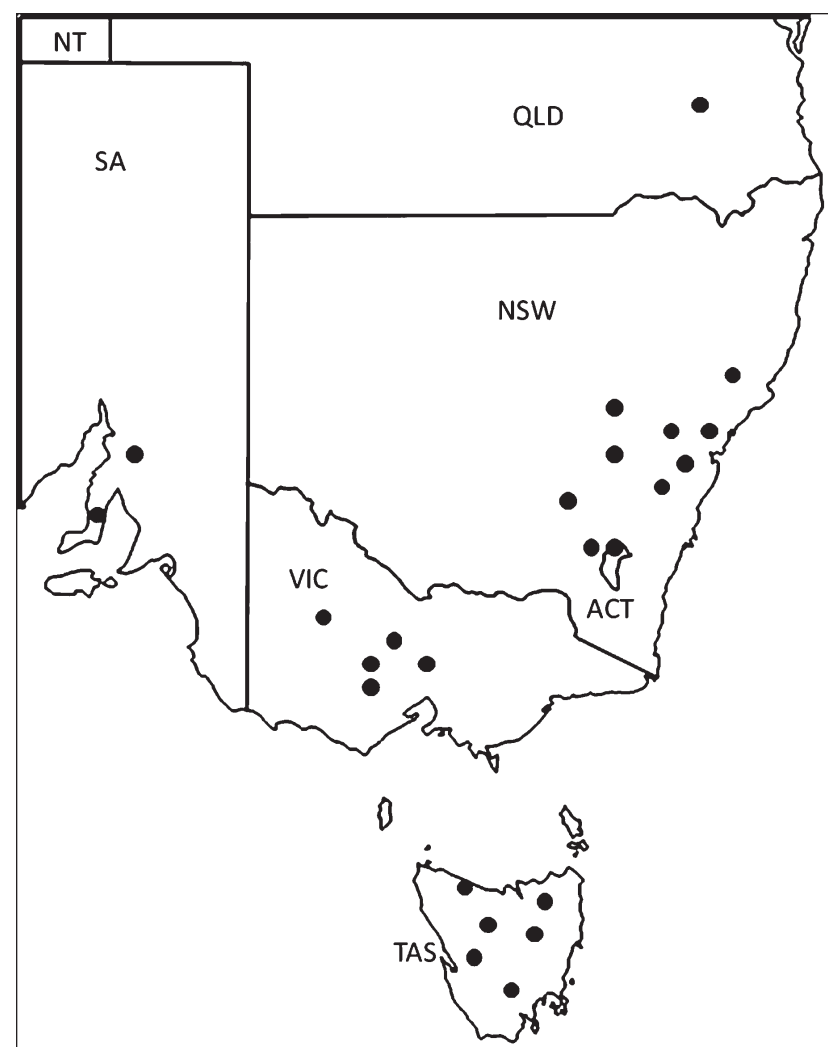

Fig. 47. Distribution of species of Glycaspis (Synglycaspis) (shown by "•") in south-eastern Australia. (Not to scale). NT Northern Territory; SA - South Australia; QLD - Queensland; NSW - New South Wales; ACT - Australian Capital Territory; VIC - Victoria; TAS - Tasmania.

cant variation in thickness of third, fourth and fifth stage gall (Fig. 46). The first principal component value of gall length, width and height $(\mathrm{C} 1=0.532$ height +0.632 length +0.562 width; all values in $\mathrm{mm}$ ) explains $92.5 \%$ of variation.

\section{DISCUSSION}

Twenty named gall inducing species of Glycaspis (Synglycaspis) are currently recognized (Moore, 1961, 1970, 1979, 1985, 1988; Hollis, 2004), in addition to the possible new species in this paper (Fig. 47). These species induce different types of galls on the foliage of 22 species of Eucalyptus subgenus Eucalyptus. Seventeen out of the 20 known species of Glycaspis (Synglycaspis), which occur in South Eastern Australia are monophagous, developing on specific species of Eucalyptus (Hollis, 2004). The same dictum appears to apply to $G$. (S.) sp. on E. macrorhyncha. Only, G. (S.) amplificata Moore, G. (S.) inclusa Moore and $G$. (S.) occulta Moore, confined to the Sydney Basin, South-Eastern Highlands-NSW North Coast and SouthEastern Highlands-Tasmanian-Northern Slope bioregions develop on two different Eucalyptus species. Thirteen of the named Glycaspis (Synglycaspis) species and G. (S.) sp. on E. macrorhyncha occur in cool [mean winter temperature (June-August) $8-12^{\circ} \mathrm{C}$ ] and high rainfall [winter (June-August) $1800 \mathrm{~mm} /$ year, summer (November-January) $800 \mathrm{~mm} /$ year] bioregions of south-eastern Australia

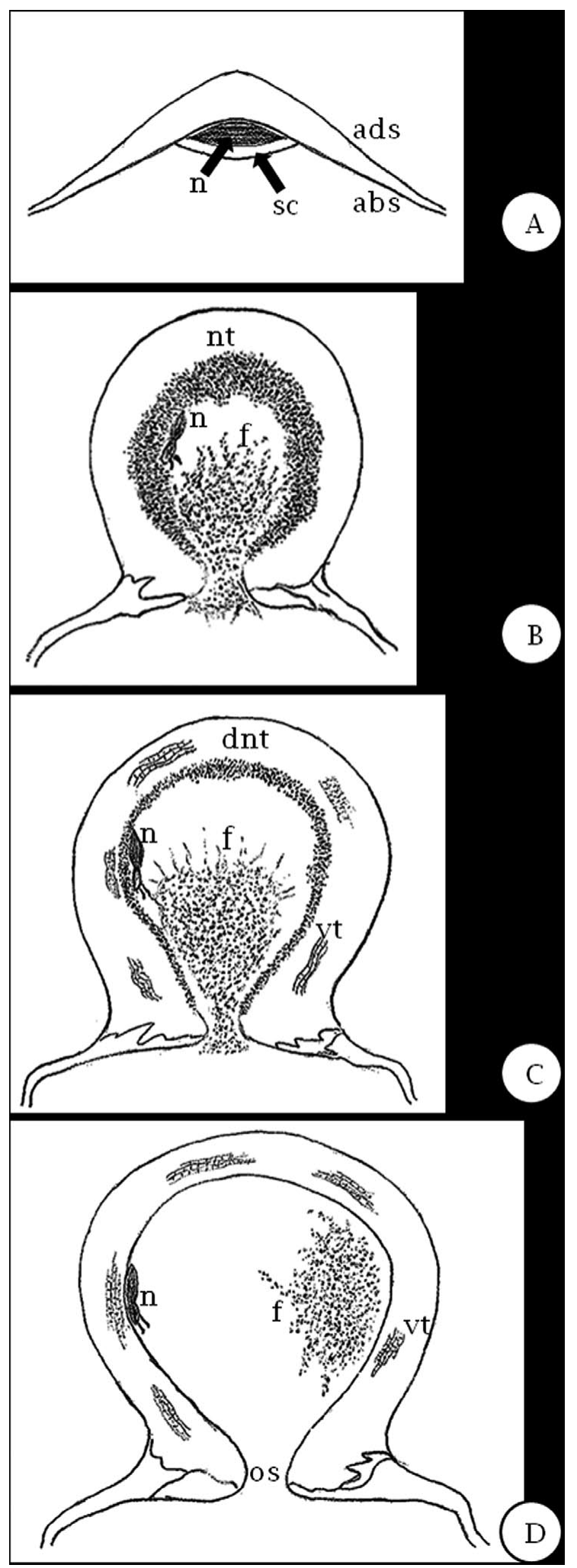

Fig. 48. Gall development on leaf of E. macrorhyncha, verticalsectional views ( $\mathrm{n}$ - nymph; sc - sugary covering; abs - abaxial leaf surface; ads - adaxial leaf surface; $\mathrm{f}$ - sugary filaments; $\mathrm{nt}$ - nutritive tissue; $\mathrm{dnt}$ - degenerated nutritive tissue; $\mathrm{vt}$ - vascular trace; os - ostiole) (not to scale). A - gall initiation by the first instar showing hyperplasied mesophyll. B - gall (near-final shape) of the second instar. Sugary material plugging the ostiole. C - gall of the third and fourth instars with thinner gall wall. D - gall of the fifth instar showing shrunken sugary material and wide ostiole due to dessication. 
(New South Wales, Australian Capital Territory, Victoria and Tasmania). These 13 species occur at elevations from 500 to $1800 \mathrm{~m}$ a.s.1. Glycaspis (Synglycaspis) morgani on $E$. diversifolia in the Flinders Lofty Block Bioregion in South Australia, G. (S.) munita on E. nitida Hook. f. in the Tasmanian West Bioregion and G. (S.) surculina on E. conglomerata in South-Eastern Queensland Bioregion exist close to the coast, but at elevations of $<100 \mathrm{~m}$. Three other species of Glycaspis (Synglycaspis) live in submontane regions (up to $300 \mathrm{~m}$ a.s.l.) (e.g., G. (S). inclusa, G. (S). cyrtoma Moore and $G$. $(S)$. cyta Moore). Similar temperature regimens and rainfall patterns in south-eastern Australia and the distribution of the species of Eucalyptus subgenus Eucalyptus could be the possible regulatory factors in confining the gall-inducing taxa of Glycaspis (Synglycaspis) to south-eastern Australia. This restriction of Glycaspis (Synglycaspis) on different species of Eucalyptus subgenus Eucalyptus in south-eastern Australia is based on data from Moore (1961, 1970, 1979, 1985, 1988) and Hollis (2004) which were, in high likelihood, based on single collections. Despite this deficiency, we think that these data offer an insight into the restriction of the specialist Glycaspis (Synglycaspis) to south-eastern Australia.

Recently we studied the bionomics and behaviour of an unnamed lerp-forming species of Glycaspis (Glycaspis) from E. sideroxylon A. Cunn. ex Woolls (hereafter, Glycaspis sp. on E. sideroxylon) from the Orange region (Sharma et al., 2013). Eucalyptus sideroxylon belongs to Eucalyptus subgenus Symphyomyrtus (Brooker, 2000). Because the gall-inducing $G$. (S.) sp. on E. macrorhyncha and the lerp-forming Glycaspis sp. on E. sideroxylon occur sympatrically, we compare the bionomics and behaviour of these two species. The number of eggs laid per cluster is similar (3-6) in both species. The proportion of developmental time of instars in both species is also similar: the first and second instars develop in shorter time than the later instars, each \pm 10 and $\pm 7 \mathrm{~d}$, respectively; the later instars of $G$. (S.) sp. on E. macrorhyncha and Glycaspis sp. on E. sideroxylon develop in \pm 15 and \pm 10 d, respectively. However, G. (S.) sp. on E. macrorhyncha shows only two generations/year, whereas Glycaspis sp. on E. sideroxylon shows four generations/year. Two generations of $G$. (S.) cameloides on E. obliqua have been recorded (Taylor, 1987), which match with our biological notes on $G$. $(S)$. sp. on E. macrorhyncha.

Glycaspis (S.) sp. on E. macrorhyncha deposits eggs along the abaxial surfaces of tender leaves of E. macrorhyncha, whereas $G$. sp. on E. sideroxylon deposits only along the adaxial surfaces of mature leaves of $E$. sideroxylon. Nevertheless, the shared behaviour in the two taxa during oviposition is their preference to sites proximal to stomatal apertures, a behaviour common among the Psylloidea of different families across the world (Burckhardt, 2005). The subtropical and tropical gall-inducing species of Oriental Psylloidea, such as T. jambolanae on S. cumini (Raman, 1991), T. cinnamomi Boselli (Triozidae) on more than one species of Cinnamomum Schaeff. (Lauraceae) (Hodkinson, 2009) and Diaphorina truncata Craw- ford (Liviidae) on Strychnos nuxvomica L. (Loganiaceae) (Balakrishna \& Raman, 1992) show multivoltinism with free-running life cycles completing multiple generations/ year. In contrast, univoltinism occurs in the tropical taxon Nothotrioza myrtoidis Burckhardt (Triozidae), which induces spherical, closed galls on Psidium myrtoidis O. Berg (Myrtaceae) in the Neotropics (Minas Gerais, Brazil; $20^{\circ} 06^{\prime} \mathrm{S}$; 4329' W; $1300 \mathrm{~m}$ a.s.1.) (Carneiro, Burckhardt \& Isaias, 2012). Gravid N. myrtoidis deposit eggs along the margins of young leaves of $P$. myrtoidis in October and adults emerge in the following September. The oviposition behaviour of $G$. (S.) sp. on E. macrorhyncha is similar to that of T. jambolanae, but the stark difference is that gravid $T$. jambolanae oviposit along the marginal sutures of tender leaves, whereas gravid $G$. (S.) sp. on E. macrorhyncha deposit on the abaxial surfaces of tender leaves, somewhat similar to the oviposition behaviour of the roll-gall inducing $D$. truncata, which deposit eggs on the abaxial surfaces of mature leaves of $S$. nuxvomica (Balakrishna \& Raman, 1992).

In the immatures, the apical antennal bristles are unequal, similar to those shown in Bactericera cockerelli Šulc (Triozidae) (Arras, Hunter \& Bextine, 2012) and Trioza apicalis Förster (Triozidae) (Kristoffersen et al., 2006). Kristoffersen et al. (2006) and Arras et al. (2012) suggest that these unequal apical bristles are olfactory in function. The rhinaria near the apices of flagellomeres in the adult antennae of $G$. (S.) sp. on E. macrorhyncha are highly likely to be used as chemoreceptors directly in host selection, as shown in various Cixiidae (Hemiptera) (Brożek \& Bourgoin, 2013) in a heterogeneous natural environment. The trichoid sensilla possibly function as mechanosensors as shown in Diaphorina citri Kuwayama (Liviidae) (Onagbola et al., 2008).

The four pairs of sensilla at the labial tips of immatures and adults of $G$. (S.) sp. on E. macrorhyncha appear morphologically similar to those shown in Glycaspis sp. on E. sideroxylon (Sharma et al., 2013) and Ctenarytaina eucalypti (Sharma et al., 2014a) and in several species of Cixiidae (Brożek \& Bourgoin, 2013). Among the Cixiidae, these labial tip sensilla have been indicated to enable the Cixiidae in exploring the plant surface. We propose a similar function is possible in the labial structures of $G$. (S.) sp. on E. macrorhyncha.

Among the gall inducing Psylloidea, gall induction commences with the feeding action of the first instar (Taylor 1985, 1990; Raman, 1991). One such example is the gallinducing $T$. jambolanae on S. cumini, where the first instar settles on the stomatal aperture and commences feeding. Its feeding on the mesophyll cells stimulates multiple leaf responses, of which the earliest is the generation of ledge-like growth around the immature, enclosing it completely and resulting in a spherical, closed gall (Raman, 1991). Gall initiation by $G$. (S.) sp. on E. macrorhyncha on the leaves of E. macrorhyncha is similar to that in the $T$. jambolanae-S. cumini interaction, but the difference is that the immature never gets enclosed by the hyperplasied host tissue. An ostiole remains until the end of the life cycle of 
the psylloid but, as a developmental adaptation, immatures of $G$. (S.) sp. on E. macrorhyncha accumulate filamentous sugary material. Secretions of the filamentous sugary material that plugs the gall ostiole are plentiful in the early stages of gall development, but production lessens as the immature matures (see Figs 32, 33) but, with the maturation of the immature, production of this material wanes. This sugary material dries with gall growth, thus shrinking from a loosely fluffy, filamentous ball during the occupation of the first and second instars to a tightly compressed ball when the fifth instar is ready to exit. At the time of exit of the fifth instar, the sugary material is so shrunken that adequate space for the immature to exit is available.

In terms of responses of E. macrorhyncha leaf tissue to the action of $G$. (S.) sp., two distinct patterns are evident. During oviposition, the leaf responds passively, whereas during feeding of the younger instars leading to gall development, the same leaf responds actively.

Gravid females of $G$. $(S)$. sp. on E. macrorhyncha insert egg pedicels into E. macrorhyncha leaf tissue by puncturing a narrow and long hole. The oviposition fluid secreted into this hole during pedicel insertion elicits a modest regenerative response with a few parenchyma cells turning metaplasied, whereas other parenchyma cells around the pedicel remain inactive and accumulate secondary metabolic compounds. In 7-10 d, the cells lining the hole develop intense cutinization indicating that the leaf isolates and insulates the foreign object, viz., the pedicel, inserted into it. This differs from the egg deposition of Schedotrioza, another Australian Eucalyptus inhabiting, gall-inducing triozid, where the eggs lack a pedicel and are inserted immediately beneath the epidermis. In these species, the females bear short, wide and intensely serrate ventral valvulae (Taylor, 1992). The females of G. (S.) sp. on E. macrorhyncha, in contrast, possess long and slender valvulae and therefore are able to puncture an elongate hole into the host leaf. Taylor (1992) and Hodkinson (2009), describing the oviposition behaviour and egg morphology of different Psylloidea, indicate that the role of the pedicel is principally to ensure adequate moisture supply to the embryo. In the present work, we demonstrate that the few active parenchyma cells in the vicinity of the pedicel enable nutrient supply, in addition to water, to the developing embryo via the embedded pedicel, as shown in Bemisia argentifolii Gennadius (Hemiptera: Aleyrodidae) (Buckner et al., 2002)

Feeding action of the first instar triggers gall development although the near final spherical gall shape is realized in $14 \mathrm{~d}$, when the second instar is about to moult to the third. Modest compensatory growth manifests during the inhabitation time of the later (the third, fourth and fifth) instars. These dramatic changes can be correlated with the feeding behaviours of the inhabiting immatures: the first and second instars feed on "specialized" mesophyll parenchyma, designated as "nutritive cells" in this paper. The third and subsequent instars feed on phloem sap. The host tissue response, therefore, is maximal during occupation of the first and second instars, whereas it is minimal during the occupation of the later developmental stages. Notably, the active nutritive parenchyma cells that develop during early stages of development shrivel, demonstrated by the thin walls of galls occupied by the later immature stages (Fig. 48). Moreover the lack of feeding pressure and consequent stress also manifest in such a way that the parenchyma cells along the upper edges of the galls (the erstwhile upper mesophyll parenchyma) accumulate secondary metabolic compounds.

During feeding action of the first instar (7-10 d), the site at which the immature settles and feeds rapidly undergoes hypertrophy and hyperplasia, modifying the normal differentiation course of the primordial leaf into a mass of multi-layered homogeneous parenchyma. This site displays cell multiplication occurring in a radiating pattern towards the adaxial epidermis of the leaf. Clear morphogenetic gradients ("cecidogenetic gradients", sensu Mani, 1964) involving proliferating cells are apparent around the stylet tip (= feeding site) establishing a neoformed meristem of concentric rings of dividing cells. Cells with secondary metabolic inclusions occur in this region, but as specific columns (as seen in transverse sectional views Fig. 29) among proliferating cells, clearly regulating the morphogenetic course. The nutritive cells - from which the immature feeds - are active and dynamic. These nutritive cells include wide walls with electron dense outer layers and abnormally dilated interwall space. Wide walls with dilated interwall spaces have been shown in infections by Glomus versiforme (P. Karst.) S.M. Berch (Glomeromycetes: Glomerellaceae) on Cucumis sativus L. (Cucurbitaceae) and been explained as due to accumulation of the protein $\alpha$-expansin in enhancing plant cell wall extensibility (Balestrini, Cosgrove \& Bonfante, 2005). In the nutritive cells in the galls on the leaves of E. macrorhyncha, the wide walls with dilated interwall space indicate the stress experienced by the plant and these cells metabolize nutrients to neutralize the stress; indeed the actively feeding early instars of Glycaspis (Synglycaspis) sp. on E. macrorhyncha benefit from this event, through mobilization of nutrients. These nutritive cells, in addition to presenting the characteristic cytological features of nutritive cells shown in insect-induced galls (Bronner, 1992), such as extensive and dynamic intercellular communication channels, also show desmosomal condensations and endosomes of unique morphology. Active desmosomal condensations along the wall pores indicates a rapid symplastic movement of nutrients to the nutritive cells from where the immatures draw nutrients. The unique endosomes, particularly in the parenchyma cells, which come under the direct feeding impact of $G$. (S.) sp. on E. macrorhyncha, indicate the altered hormone metabolism that eventuates in these cells in an effort to maintain cell integrity such as cell polarity and signal pathways. The role of endosomes in plant growth and hormone signal functions in response to pathogen elicitors has been adequately illustrated (Contento \& Bassham, 2012). In about $20 \mathrm{~d}$, the immature moults to the third instar and the parenchyma cells on which the first and second instars fed from turn exhausted with distended 
cell membranes, presenting hyaline cytoplasm, including cell debris and secondary metabolic inclusions. When the immature moults into the third instar, it ceases to feed on the multilayered nutritive parenchyma that lines the gall chamber and shifts its feeding from parenchyma to phloem strands. Consequently the former nutritive parenchyma cells shrivel. With further ageing, the cells that compose the gall wall elongate in the horizontal axis, due to stretching in galls, accumulate secondary metabolic compounds and calcium oxalate druses. In mature galls inhabited by the fifth instar, the gall metabolism changes to result in the differentiation of intensely thick-walled sclereids. Feeding on phloem ducts by the later instars is vital in inducing desiccation in older galls. When the later instars feed on phloem they flood the vascular tissues with salivary proteins, such as amylase and cellulase (Sharma et al., 2014b), which obviously disrupt water movement. Overall changes in the cell dynamics of the mature gall indicate that the gall tissue suffers desiccation, leading to the shrinkage of the filamentous sugary materials and widening of the ostiole, thus enabling the exit of the fifth instar to moult into adult outside the gall.

\section{CONCLUSION}

The pouch gall inducing Glycaspis $(S$.) sp. on E. macrorhyncha shows similarities in the morphology of immature stages, oviposition behaviour and secretion of sugary material, when compared with other species of Glycaspis, e.g., Glycaspis sp. on E. sideroxylon. Several traits in gall induction by $G$. $(S$.) sp. on E. macrorhyncha are similar to those shown in many Triozidae. This work highlights the passive response of host-leaf tissue following oviposition and its active and dramatic response of gall development during feeding by the first and the second instars. The growth rates during gall development gradually decelerate, when the instar turns from the second to the third. It demonstrates the clear requirement for gall development to coincide with the availability of actively metabolizing meristematic host tissue and highlights the adaptational integration between the gall-inducing $G$. (S.) sp. on E. macrorhyncha and its host.

ACKNOWLEDGEMENTS. We are grateful to D. Burckhardt (Naturhistorisches Museum Basel, Basel, Switzerland) and P. Ladiges (University of Melbourne, Melbourne, Australia) for their insightful remarks on the draft manuscript. Remarks of two anonymous reviewers substantially improved the quality of the paper. We owe our thanks to them as well.

\section{REFERENCES}

Albert S., Padhiar A., Gandhi D. \& Nityanand P. 2011: Morphological, anatomical and biochemical studies on the foliar galls of Alstonia scholaris (Apocynaceae). - Rev. Bras. Bot. 34: $343-358$.

Arras J., Hunter W. \& Bextine B. 2012: Comparative analysis of antennae sensory arrays in Asian citrus psyllid, Diaphorina citri and potato psyllid Bactericera cockerelli (Hemiptera). Southw. Entomol. 37: 1-12.

Balakrishna P. \& Raman A. 1992: Cecidogenesis of leaf galls of Strychnos nux-vomica (Loganiaceae) induced by the jump- ing plant louse species Diaphorina truncata (Homoptera: Psylloidea: Psyllidae). - Entomol. Gen. 17: 285-295.

Balestrini R., Cosgrove D.J. \& Bonfante P. 2005: Differential location of $\alpha$-expansin proteins during the accommodation of root cells to an arbuscular mycorrhizal fungus. - Planta 220: 889-899.

Bouyjou B. \& NGuyen T.-X. 1974: Observations sur la morphogenèse et la structure de la galle de Trioza alacris Flor (Homoptera - Psyllidae) sur Laurus nobilis L. — Marcellia 38: 49-56.

BRONNER R. 1992: The role of nutritive cells in the nutrition of cynipids and cecidomyiids. In Shorthouse J.D. \& Rohfritsch O. (eds): Biology of Insect-Induced Galls. Oxford University Press, New York, pp. 118-140.

Brooker M.I.H. 2000: A new classification of the genus Eucalyptus L'Hér. (Myrtaceae). - Austral. Syst. Bot. 13: 79-148.

BRożeK J. \& BourgoIN T. 2013: Morphology and distribution of the external labial sensilla in Fulgoromorpha (Insecta: Hemiptera). - Zoomorphology 132: 33-65.

Buckner J.S., Freeman T.P., Ruud R.L., Chu C.C. \& Henneberry T.J. 2002: Characterization and functions of the whitefly egg pedicel. - Arch. Insect Biochem. Physiol. 49: 22-33.

BurCKHARDT D. 1991: Boreioglycaspis and spondyliaspidine classification (Homoptera: Psylloidea). — Raffles Bull. Zool. 39: $15-52$.

BURCKHARDT D. 2005: Biology, ecology and evolution of gall-inducing psyllids (Hemiptera: Psylloidea). In Raman A., Schaefer C.W. \& Withers T.M. (eds): Biology, Ecology and Evolution of Gall-Inducing Arthropods. Vol. 1. Science Publishers, New Hampshire, pp. 143-157.

Burckhardt D., Ouvrard D., Queiroz D. \& Percy D. 2014: Psyllid host-plants (Hemiptera: Psylloidea): resolving a semantic problem. - Fla Entomol. 97: 242-246.

Carneiro R.G.S., Burckhardt D. \& Isaias R.M.S. 2012: Biology and systematics of gall-inducing triozids (Hemiptera: Psylloidea) associated with Psidium spp. (Myrtaceae). - Zootaxa 3620: $129-146$

Contento A.L. \& Bassham D.C. 2012: Structure and function of endosomes in plant cells. - J. Cell Sci. 125: 1-8.

Department of EnVironment, Government of Australia 2012: Australia's bioregions - maps. http://www.environment.gov. au/topics/land/national-reserve-system/science-maps-and-data/australias bioregions-ibra/australias. Accessed on 20 March 2014.

HodKINSON I.D. 2009: Life cycle variation and adaptation in jumping plant lice (Insecta: Hemiptera: Psylloidea): a global synthesis. - J. Nat. Hist. 43: 65-179.

Hollis D. 2004: Australian Psylloidea: Jumping Plantlice and Lerp Insects. The Australian Biological Resource Study, CSIRO, Canberra, 216 pp.

Kristoffersen L., Hallberg E., Wallén R. \& Anderbrant O. 2006: Sparse sensillar array on Trioza apicalis (Homoptera, Triozidae) antennae - an adaptation to high stimulus levels? Arthr. Struct. Dev. 35: 85-92.

Mani M.S. 1964: Ecology of Plant Galls. W. Junk, The Hague, $434 \mathrm{pp}$.

Meyer J. 1987: Plant Galls and Gall Inducers. Gebrüder Bornträger, Stuttgart, $291 \mathrm{pp}$.

Moore K.M. 1961: Observations on some Australian forest insects. 7. The significance of the Glycaspis spp. (Hemiptera: Homoptera, Psyllidae) associations with their Eucalyptus spp. Hosts; erection of a new subgenus and descriptions of thirtyeight new species of Glycaspis. — Proc. Linn. Soc. N.S.W. 86: 128-167.

Moore K.M. 1970: Observations on some Australian forest insects. 23. A revision of the genus Glycaspis (Homoptera: Psyl- 
lidae) with descriptions of seventy-three new species. - Aust. Zool. 15: 248-342.

Moore K.M. 1979: A new species of Glycaspis Taylor (Homoptera: Psyllidae) from Victoria. - J. Aust. Entomol. Soc. 18: 287-288.

Moore K.M. 1983: New species and records of Glycaspis Taylor (Homoptera: Spondyliaspidae) with phyletic groupings. $-J$. Aust. Entomol. Soc. 22: 177-184.

MOORE K.M. 1985: Four new species of Glycaspis Taylor (Homoptera: Spondyliaspididae) from some endangered species of Eucalyptus. - Proc. Linn. Soc. N.S.W. 108: 71-78.

MoORE K.M. 1988: Associations of some Glycaspis species (Homoptera: Spondyliaspididae) with their Eucalyptus species hosts. - Proc. Linn. Soc. N.S.W. 110: 19-24.

Onagbola E.O., Meyer W.L., Boina D.R. \& Stelinski L.L. 2008: Morphological characterization of the antennal sensilla of the Asian citrus psyllid, Diaphorina citri Kuwayama (Hemiptera: Psyllidae), with reference to their probable functions. - Micron 39: 1184-1191.

Raman A. 1991: Cecidogenesis of leaf galls on Syzygium cumini (L.) Skeels (Myrtaceae) induced by Trioza jambolanae Crawford (Homoptera: Psylloidea). - J. Nat. Hist. 25: 653-663.

Sharma A., Raman A., Taylor G. \& Fletcher M. 2013: Nymphal development and lerp construction of Glycaspis sp. (Hemiptera: Psylloidea) on Eucalyptus sideroxylon (Myrtaceae) in central-west New South Wales, Australia. - Arthr. Struct. Dev. 42: 551-564.

Sharma S., Raman A., Taylor G.S., Fletcher M.J. \& Nicol H. 2014a: Development, feeding and oviposition behaviour of Ctenarytaina eucalypti (Maskell) (Hemiptera: Psylloidea: Aphalaridae) on Eucalyptus globulus (Myrtaceae) in the central tablelands of New South Wales. - Aust. Entomol. doi: 10.1111/aen.12103.

Sharma A., Khan A.N., Subrahmanyam S., Raman A., Taylor G.S. \& FLETCHER M.J. 2014b: Salivary proteins of plant-feeding hemipteroids - implication in phytophagy. - Bull. Entomol. Res. 104: 117-136.

TAYLOR G.S. 1985: The taxonomic status of Schedotrioza multitudinea (Maskell) (Homoptera: Triozidae) with notes on its biology. - J. Aust. Entomol. Soc. 24: 305-312.
TAYLOR G.S. 1987: The gall forming Psylloidea of Eucalyptus obliqua in the Mount Lofty Ranges of South Australia. - $J$. Aust. Entomol. Soc. 26: 223-228.

TAYLOR G.S. 1990: Revision of the genus Schedotrioza Tuthill \& Taylor (Homoptera: Psylloidea: Triozidae). — Inver. Taxon. 4: 721-751.

TAYLOR G.S. 1992: The structure of the eggs of some Australian Psylloidea (Hemiptera). — J. Aust. Entomol. Soc. 31: 109-117.

Taylor G.S., Austin A.D., Jennings J.T., Purcell M.F. \& WheelER G.S. 2010: Casuarinicola, a new genus of jumping plant lice (Hemiptera: Triozidae) from Casuarina (Casuarinaceae). - Zootaxa 2601: 1-27.

Taylor G.S., Jennings J.T., Purcell M.F. \& Austin A.D. 2011: A new genus and ten new species of jumping plant-lice (Hemiptera: Triozidae) from Allocasuarina (Casuarinaceae) in Australia. - Zootaxa 3009: 1-45.

TaYlor G.S., Jennings J.J., Purcell M.F. \& Austin A.D. 2013: Three new Australian species of Trioza Foerster (Hemiptera: Triozidae) with a remarkable adaptation to oviposition on articulate branchlets of Allocasuarina (Casuarinaceae). - Aust. J. Entomol. 52: 42-52.

TAYLOR K.L. 1960: Additional information on the Australian genera of the family Psyllidae (Hemiptera: Homoptera). - Aust. J. Zool. 8: 383-391.

YANG M.-M. \& RAMAN A. 2007: Diversity, richness and patterns of radiation among gall-inducing psyllids (Hemiptera: Psylloidea) in the Orient and Eastern Palearctic. - Orient. Insests 41: 55-65.

Yen A.L. 2002: Short-range endemism and Australian Psylloidea (Insecta: Hemiptera) in the genera Glycaspis and Acizzia (Psyllidae). - Invert. System. 6: 631-636.

VSN InTERNATIONAL 2013: GenStat for Windows. VSN International, Hempel Hempstead, Hertfordshire.

White T.C.R. 1972: The production of amylase in the faeces of psyllid larvae with special reference to the lerps of Cardiaspina densitexa. - J. Insect Physiol. 18: 2359-2367.

Received May 7, 2014; revised and accepted October 14, 2014 Prepublished online December 1, 2014 